NBER WORKING PAPER SERIES

\title{
A CURRENCY OF ONE'S OWN? AN EMPIRICAL INVESTIGATION ON DOLLARIZATION AND INDEPENDENT CURRENCY UNIONS
}

\author{
Sebastian Edwards \\ Igal Magendzo \\ Working Paper 9514 \\ http://www.nber.org/papers/w9514 \\ NATIONAL BUREAU OF ECONOMIC RESEARCH \\ 1050 Massachusetts Avenue \\ Cambridge, MA 02138 \\ February 2003
}

Previous versions of this paper were presented at the conference on Currency Unions organized by the Riksbank and the IIES, held in Stockholm in May, 2002, and at the LACEA Annual Meetings, held in Madrid in October 2002. We have benefited from discussions with John Cochrane, Barry Eichengreen, Eduardo Engel, Ed Leamer, Robert Barro and Andy Rose. We thank our discussants Lars Svensson and Hang Genberg for many helpful comments. Marcela Aurelio provided wonderful assistance. The views expressed herein are those of the author and not necessarily those of the National Bureau of Economic Research.

(C)2003 by Sebastian Edwards and Igal Magendzo. All rights reserved. Short sections of text not to exceed two paragraphs, may be quoted without explicit permission provided that full credit including Cnotice, is given to the source. 
A Currency of One's Own? An Empirical Investigation on

Dollarization and Independent Currency Unions

Sebastian Edwards and Igal Magendzo

NBER Working Paper No. 9514

February 2003

JEL No. F3, F4

\begin{abstract}
In this paper we analyze whether "common currency" countries - that is, dollarized and independent currency union countries - have outperformed countries that have a currency of their own. The paper is empirical and estimates jointly the probability of being a common currency country and "outcome" equations for growth, volatility and inflation. We find that both type of common currency countries have lower inflation than countries with a domestic currency. Dollarized countries have lower growth and higher volatility than countries with a domestic currency. Currency unions, on the other hand, have higher growth and higher volatility than countries with a currency of their own.
\end{abstract}

Sebastian Edwards

UCLA

Anderson Graduate School of Business

110 Westwood Plaza, Suite C508

Box 951481

Los Angeles, CA 90095-1481

and NBER

sedwards@anderson.ucla.edu
Igal Magendzo

Central Bank of Chile

imagendzo@bcentral.cl 
“...almost all independent countries choose to assert their nationality by having, to their own inconvenience and that of their neighbors, a peculiar currency of their own..."

John Stuart Mill

Principles of Political Economy, 1848

\section{Introduction}

The recurrence of currency crises in emerging countries has generated an intense debate on exchange rate policies. Pegged-but-adjustable exchange rate regimes have rapidly lost adepts, while hard pegs and freely floating rates have gained in popularity (See Summers 2000 and Fischer, 2001). Recently, a number of economists have gone as far as arguing that (many) emerging nations should completely give up their national currencies, and join a currency union. ${ }^{1}$

In principle, currency unions can take two forms. First, a country may adopt another nation's currency as its own. When the other nation is an advanced country this monetary arrangement has come to be known by the general name of "dollarization.", 2 Under "dollarization" the country in question completely gives up monetary independence, and monetary policy is run by the advanced nation's central bank. Countries can "dollarize" in a unilateral fashion - in which case they will loose the revenue from seignorage --, or they can sign a monetary treaty with the advanced country and share seignorage. ${ }^{3}$ Under the second type of currency union, a group of countries creates a new currency that is common to the group. ${ }^{4}$ Under this option, monetary policy is run by a common central bank, the members of the currency union share seinorage, and the common currency's exchange rate may float relative to other currencies. In the rest of this paper we will refer to this type of monetary regime as an "independent currency

\footnotetext{
${ }^{1}$ See Alesina, Barro and Tenreyro (2002) for a discussion on the conditions under which emerging countries will benefit from giving up their currency.

2 Although this option is known as "dollarization" the advanced country's currency needs not be the dollar. It could be any other "convertible" currency.

${ }^{3}$ In early 2000 then Florida's senior senator Connie Mack introduced legislation into the U.S. Senate aimed at sharing seignorage with countries that decided to adopt the U.S. dollar as legal tender. The bill, however, did not move in the legislative process.

${ }^{4}$ The Euro is, perhaps, the best-known example of this type of currency union.
} 
union" or ICU. ${ }^{5}$ Panama and Monaco are good examples of dollarized countries. The East Caribbean Currency Area (ECCA) and the Communante Financiere de l'Afrique (CFA), on the other hand, are good representatives of what we have called an independent currency union.

Recently, some emerging countries have decided to give up their currencies and officially dollarize their economies. In 2000, for example, and in the midst of a major crisis, Ecuador gave up its currency, the Sucre, and adopted the U.S. dollar. El Salvador adopted the dollar during 2001; and in May 2001, the dollar became legal tender in Guatemala. In other countries, however, politicians have systematically refused to consider dollarization, even in the face of major and costly financial crises. This was the case of Argentina, for instance, during late 2001 and early 2002.

A number of authors have argued that countries - and in particular, emerging countries -- that give up their currency will tend to outperform countries with a currency of their own. According to this view, not having a domestic currency will have two major positive effects on economic performance: First, inflation will be lower in common currency countries than in nations with their own currency. Alesina and Barro (2001 p. 382), for instance, have argued that adopting an advanced nation's currency "eliminates the inflation-bias problem of discretionary monetary policy." Second, according to this view, countries that give up their currency will tend to grow faster than countries with a domestic currency. This growth effect is supposed to take place through two channels: (a) A common currency will tend to result in lower interest rates, higher investment and faster growth (Dornbusch 2001). And (b), by eliminating exchange rate volatility, a common currency is supposed to encourage international trade; this, in turn, will result in faster growth. Rose (2000), and Rose and Van Wincoop (2001), among others, have emphasized this trade channel. ${ }^{6}$ Other authors, however, have voiced skepticism regarding the alleged benefits of "common currency" regimes. According to an alternative view that goes back at least to Meade (1950), countries with a hard peg will

\footnotetext{
${ }^{5}$ Strictly speaking there is a third type of currency union: when a small country adopts a non-convertible currency from another country as legal tender. In this case the "credibility" effect of having monetary policy run by an advanced nation's central bank will not be present. Thus, in the empirical analysis that follows we group this third category with what we have called independent currency unions.

6 On analytical aspects of dollarization see Calvo (1999) and Eichengreen and Haussman (1999); for an interesting theoretical analysis see Cooper and Kempf (2001).
} 
have difficulties accommodating external shocks, including terms of trade and world interest rate disturbances. This, in turn, will be translated into greater instability and, under some circumstances, will lead to lower economic growth (Fischer 1976; Parrado and Velasco 2002). Frankel (1999) has taken a more nuanced view, and has argued that there is no unique recipe on exchange rate policy; while some countries will benefit from hard pegs, for other countries a floating regime will be more appropriate. And according to Eichengreen (2001) the evidence on the relationship between monetary regimes and growth is inconclusive, and does not support the claim that dollarization - or any exchange rate regime, for that matter - is an important determinant of growth.

Surprisingly, until recently there have been very few formal empirical studies on the economic consequences of common currencies. In particular, international comparative studies on alternative exchange rate and monetary regimes have traditionally ignored common currency countries. For instance, the comprehensive study on exchange rate regimes, growth and inflation by Gosh et al (1995), does not include nations that do not have a currency of their own. Likewise, the IMF (1997) study on alternative exchange rate systems excludes common currency countries, and the recent paper by Levy-Yeyeti and Sturzenegger (2001) on exchange rates and economic performance excludes nations that do not have a central bank of their own. This lack of empirical evidence means that countries that are contemplating giving up their currency have very little information on how other countries have historically performed under this monetary regime. Most existing evidence on dollarization is based on the experience of a single country: Panama, which has used the U.S. dollar as legal tender since $1904{ }^{7}$

Recently, Andrew Rose and a series of collaborators have analyzed in great detail the effects of common currencies on the volume of international trade - see, for instance, Rose (2000), Engel and Rose (2002), and Frankel and Rose (2002). This interesting and increasingly influential research has concluded that, with other things given, countries with a common currency tend to trade among themselves more intensively than countries

\footnotetext{
7 Goldfjan and Olivares (2001) use econometrics to evaluate Panama's experience with dollarization. Moreno-Villalaz (1999) provides a detailed analysis of the Panamanian system. Bogetic (2000) describes several aspects of dollarization in a number of countries. As far as we know, Rose and Engel (2000) and Edwards (2001) are the first two papers to provide a statistical and econometric analysis of economic performance in dollarized countries and/or currency unions. See also the papers in Levy_Yeyati and Stuzenegger (2003).
} 
that have a domestic currency. These analyses, however, do not make a distinction between the two types of "common currency" regimes discussed above: strictly dollarized and independent currency unions (ICU). For instance, an inspection of the data sets used by Engel and Rose (2002) and Frankel and Rose (2002) indicates that they treat dollarized and ICU nations as a homogeneous group. Moreover, their sample is tilted towards ICU countries, and has relatively few observations on strictly dollarized nations. From a policy perspective, however, it is important to make a distinction between these two common currency regimes. The reason for this is that the two regimes have important differences in terms of independence of monetary policy, seignorage, and capacity to absorb external shocks. Making a distinction between dollarized and ICU countries is also important from a political economy point of view. As Frieden (2003) has argued, adopting another country's currency is usually perceived as giving up sovereignty, and has serious political costs. These political costs may be reduced, however, if the country becomes a partner in an ICU. It is even possible that by joining an ICU the country reaps most of the benefits of a common currency, without incurring in the political costs associated with this measure.

The purpose of this paper is to analyze whether common currency countries both dollarized and ICU countries - have outperformed countries that have a currency of their own. The paper is empirical and proceeds in steps: we first analyze the behavior of all common currency countries, and compare them with countries with domestic currencies; we then turn to a comparison of the dollarized and ICU countries. Performing these type of international comparisons, however, is not easy. The problem is how to define an appropriate "control" group with which to compare the common currency nations. Since the adoption of a common currency is not a "natural experiment," using a broad control group of all countries with a domestic currency is likely to result in biased estimates. In this paper we tackle this issue by using a treatment effects model that estimates jointly the probability of being a common currency country, and outcome equations for GDP growth, inflation and volatility (Maddala, 1983; Heckman et. al. 1997; Green, 2000; Wooldridge 2002). Some authors - most notably Alesina and Barro (2001, 2000) - have analyzed the conditions under which a (small) economy would benefit from giving up its currency. In contrast, we are interested in finding out how countries with a 
long experience with a common currency regime have performed, relative to countries with a currency of their own.

Before proceeding, it is useful to point out the ways in which our analysis differs from other related work in this general area. First, we have made an effort to include data on both dollarized and ICU countries. This has not been easy, as most strictly dollarized countries are very small and their data are not included in readily available data sets. After significant effort we were able to obtain data on GDP per capita growth and inflation for 20 strictly dollarized countries. We also use data on 32 countries that are members of an independent currency union. Our data set, then, is significantly more general than the data set used by other researchers. Second, we focus directly on the most important macroeconomic variables - real GDP per capita growth, inflation and growth volatility. Other studies, in contrast, have analyzed performance in an indirect fashion, and have focused on ancillary variables such as the level of international trade and/or interest rates. For instance, Edwards (1999), and Powel and Sturzenegger (2003) have investigated the way in which the exchange rate/monetary regime affects interest rate behavior, and the cost of capital. On the other hand, Frankel and Rose (2002) have analyzed the way in which currency unions affect bilateral trade and, through this channel, economic growth. ${ }^{8}$ Third, we use a "treatment effects model" to estimate the way in which dollarization affects the macroeconomic variables of interest. And fourth, we make a distinction between strictly dollarized and ICU countries.

The rest of the paper is organized as follows: In Section II we provide a preliminary analysis of historical experiences with "common currencies." In Section III we use treatment regressions to analyze the effects of "common currencies" on a group of macroeconomic variables. In Section IV we go a step further and disaggregate the common currency countries into strictly dollarized and ICU countries. In Section V we undertake a robustness analysis, and we analyze how different samples and estimation techniques affect the results. In particular, we report results on comparative performance obtained from an analysis that uses "matching estimators" techniques, and from using an

\footnotetext{
8 See Klein (2002) for a discussion on dollarization and trade, including a comprehensive bibliography on the subject.
} 
instrumental variables version of treatment regressions. Finally in Section VI we provide some concluding remarks.

\section{Common Currency Experiences During 1970-1998: A Preliminary Analysis}

\section{II.1 Some Background Discussion}

Table 1 presents a list of 52 common currency countries and territories with available data for the period 1970-1998. ${ }^{9}$ In compiling this list we have excluded countries that, while having a currency of their own, have had a long tradition of fixed exchange rates, such as Ireland before 1979 and Bermuda. ${ }^{10}$ We have divided our sample into two groups: (a) countries that use and advanced country currency as legal tender, or "strictly dollarized countries." In our sample 20 countries satisfy this criterion. (b) Other common currency countries, which we call ICUs. The majority of the ICUs use a currency that is common to the area, but is not issued by any of the individual countries. Five of them, however, use the currency of another emerging country as legal tender. It is important to note that our data set is much larger than that used by other studies. For instance, in the influential studies by Engel and Rose (2002) and Frankel and Rose (2002) there are only 26 counties that have data on real GDP per capita. Of these, only seven use another nation's currency, and only two -- Panama and Puerto Rico -- use a convertible currency as legal tender and are, thus, "strictly dollarized."

The countries and territories that have had a strictly dollarized monetary system are very small indeed. Many are city-states well integrated into their neighbors' economies - Monaco, Lichtestein, and Andorra are good examples. The largest strictly dollarized countries are Liberia, Panama and Puerto Rico. However, only Panama and Puerto Rico remain dollarized today; Liberia abandoned the system in the 1980s, when the government of President Samuel Doe decided to issue local currency as a way of

\footnotetext{
9 These countries have data for a long enough period for at least one of two variables: GDP per capita or inflation. In the rest of the paper we will use the term "countries" to refer both to independent countries and to territories.

10 Engel and Rose (2002), in contrast, consider both Ireland and Bermuda as "common currency countries." Ireland's currency is the Irish Pound or "punt." From September 1928 through March 1979 it was linked to the British Pound at parity. Bermuda's currency is the Bermuda Dollar. The Bermuda Monetary Authority issues BD $\$$ notes in several denominations (BD\$ 2, 5, 10, 20, 50 and 100). The BD\$ is linked to the U.S. Dollar at parity. It should be noticed that if these countries are added to the list of common currency countries in Table 2, the results reported in this paper remain basically unaffected.
} 
avoiding the constraints imposed by the dollarized system. ${ }^{11}$ An important characteristic of many strictly dollarized economies is that they are extremely open. In most of them there are no controls on capital mobility or on any type of international financial transactions. So much so, that in 2001 six out of the thirteen independent dollarized nations were in the OECD list of "Unfair Tax Havens," or countries whose lax financial regulations, according to the OECD, allow individuals and corporations to evade taxes. Many "dollarized” territories in Table 1 - French Guyana, Martinique, for example -have extremely close economic links with the "home country," including labor mobility, and free trade both in goods and in financial claims. These characteristics of the dollarized economies - very small and extremely open -suggest that using a broad control group of all non-dollarized countries, which are much larger and not as open, may indeed generate biased results. ${ }^{12}$

The independent currency union (ICU) countries included in our sample are larger than the dollarized nations. These ICU nations have a common central bank that, in principle, can engage in independent monetary policy. The two most important currency unions in Table 1 currently have a pegged exchange rate relative to a convertible currency: the ECCA has had a fixed exchange rate with respect to the US dollar since 1975. The CFA franc, on the other hand, was pegged to the French franc at the time of its inception in 1948. In January 1994 the CFA franc was devalued, and re-pegged with respect to the Franc, and in January 1999, when the Euro was launched, the CFA franc became pegged to the Euro. Notice that only a handful of countries in Table 1 have adopted a "common currency" monetary regime within the timeframe of our sample. This means that it is not possible to undertake a diffs-in-diffs analysis.

\section{II.2 Unconditional and "Unadjusted" Comparative Analysis: 1970-1998}

In Table 2 we present comparative data on inflation, per capita GDP growth, and the standard deviation of growth for our common currency countries. ${ }^{13}$ In order to put

11 It is not easy to date unequivocally Liberia's abandonment of the dollarized system. In July 1974 the National Bank of Liberia (NBL) was opened. In 1982 the NBL began issuing five-dollar coins, and in 1989 it began issuing five-dollar notes. On Liberia's dollarization experience see Barret (1995) and Berkeley (1993).

12 The median population of all non-dollarized emerging nations is over 100 times larger than that of the dollarized economies.

13 Our volatility measure is the standard deviation of growth, calculated over a five year period. When alterative time frames were used (i.e. seven years) the results did not change in any significant way. 
things in perspective we also present data on these three variables for an "unadjusted" control group that includes all countries with a currency of their own. The Table contains three panels: Panel A includes data on all 52 common currency countries; Panel B contains data on the "strictly dollarized" countries, or countries that have adopted a convertible currency. Finally, in Panel $\mathrm{C}$ we have included the independent currency union countries. In each panel we include data on the mean and median for the three "outcome" macroeconomic variables. In Column (C) we present data on mean and median differences between the common currency countries and the "with currency" control group. The numbers in parentheses are t-statistics for the significance of these differences. The test for the means differences is a standard $t$-statistic, while the medians differences test is a t-test obtained using a bootstrapping procedure. In making the computations for inflation differentials we have followed Rose and Engel (2002) and have excluded countries with hyperinflations. ${ }^{14}$ However, excluding these observations only affects the calculation of the means difference (quantitatively, but not qualitatively); it has no discernible effect on the computation of median differences.

The results reported in this table indicate that the difference in inflation means is quite sizable and statistically significant; on average, inflation in common currency countries as a group (Panel A) has been 9 percentage points lower than in countries with their own currency. ${ }^{15}$ The difference in inflation medians is also negative, much smaller (- 3.7 percentage points), and still statistically significant. These results also show that the rate of inflation in the strictly dollarized countries (Panel B) has been almost one half that of the ICUs (Panel C). In the latter group, however, inflation has still been significantly lower than in countries in the control group.

In terms of real per capita GDP growth, the unadjusted comparisons in Table 2 show that there are no significant differences in the means across any of the two common currency groups and the control group. The results also indicate, however, that the medians difference are significantly negative: the median rate of growth in the two common currency groups have been significantly lower - in a statistical sense - than in

\footnotetext{
${ }^{14}$ More specifically, we excluded from the control group those observations with a rate of inflation in excess of $200 \%$ per year. This resulted in 80 observations being dropped from the control group of countries with a currency of their own. See Section IV for results under alternative definitions of "high inflation."
} 
the control group of countries with a currency of their own. Finally, our results show that both groups of common currency countries have experienced greater growth volatility than the control group: both means and medians differences are significantly positive.

Although the comparisons reported in Table 2 are informative, they are subject to two potential limitations. First, these are unconditional comparisons, as no effort has been made to control for other factors potentially affecting macroeconomic performance; second, the control group may not be the appropriate one. If this is the case, the results presented in Table 2 may be subject to a "treatment bias."16 We address both of these problems in the econometric analysis reported in Sections III through V of this paper.

\section{Common Currencies and Macroeconomic Performance}

We are interested in investigating whether countries with a "common currency" regime have had a "better" macroeconomic performance than countries with a currency of their own. We focus on three dimensions of performance: GDP per capita growth, inflation and growth volatility. In principle, the exchange rate regime will affect the growth process - both the first and second moments -- through three potential channels.

First, a lower cost of capital - usually associated with "hard peg" economies --, will result in a higher rate of physical capital accumulation and a higher rate of growth of potential output. Second, a high level of international trade - which, as Rose and his coauthors have persuasively shown, is associated with common currency regimes - is likely to have a positive effect on TFP growth, and on the rate of growth of potential output. This effect has been emphasized in a number of endogenous growth models, and operates through the effect of openness on the accumulation of knowledge. And third, since the exchange rate regime will affect the country's ability to accommodate external terms of trade shocks, it will affect growth volatility and, possibly, average growth. Indeed, if as Meade (1950) and Corden (2002), among others, have argued, countries with a hard peg - and in particular countries with a "common currency"-- have more difficulties accommodating external disturbances, they will tend to exhibit a more volatile rate of growth than countries with a domestic currency. The relationship between "common currencies" and inflation is rather straightforward. A "strictly dollarized"

15 When hyperinflation countries are not excluded the means difference in inflation is a staggering $62 \%$.

16 See Maddala (1983). 
system will tend to solve the inflationary bias associated with discretionary monetary policy, allowing a small country to share the anchor country's rate of inflation. A number of studies on Panama - the strictly dollarized country par excellence - provide support for this view. Indeed, Panama's mean rate of inflation for 1970-1997 was 3.4\% per year; the median rate during this period was $1.9 \%$. Neither of these figures is significantly different from US inflation during that period. As Alesina and Barro (2000) have argued, the discretionary inflation bias will only be eliminated if the local currency is (perceived to be) linked irrevocably to the anchor currency, and will tend to have a significantly lower rate of inflation than countries with a currency of their own.

\section{III.1 The Empirical Model}

Our main interest is to undertake a comparative analysis on the conditional effect of a "common currency" on macroeconomic performance. In order to do this, we estimate jointly an "outcome equation" and the probability of being a common currency country. As in the preceding section we consider three outcome variables: GDP per capita growth, inflation and volatility. In the estimation of the inflation model we use an unbalanced panel data for 169 countries, during 1971-1998. For the growth model we used two panel data sets: The first one comprised of five year averages; the second data set is a panel with yearly data. Finally, for the volatility model we use averages of fiveyear periods to calculate the standard deviation of GDP growth. ${ }^{17}$

The empirical treatment effects model may be written as follows:

$$
y_{j t}=\mathbf{x}_{j t} \beta+\gamma \delta_{j}+\mu_{j t}
$$

\footnotetext{
${ }^{17}$ Volatility of GDP growth is measured as the standard deviation of growth in sub-periods of five years. The sub-periods correspond to the years 1974-1978, 1979-1983, 1984-1988, 1989-1993 and 1994-1998. Accordingly, the covariates were averaged out for the same sub-periods. The union, ICU and dollarized dummies where set to one for a particular sub-period if the country belonged to the respective group for at least four of the five sub-period years. In particular, Equatorial Guinea belongs to the CFA union only since 1985, but it was assigned a value of 1 for the ICU (and the union) dummy for the sub-period 1984-1988. On the contrary, even though Liberia was dollarized till 1981, it was not considered a dolarized country for the sub-period 1979-1983 (it was neither included in the control group). On the other hand, the West African Currency Union was dissolved in 1980, so Kenya, Tanzania and Uganda are not considered as part of an ICU (nor as part of the control group) for the sub-period 1979-1983.
} 


$$
\delta_{\mathrm{jt}}= \begin{cases}1, & \text { if } \delta *_{\mathrm{jt}}>0 \\ 0, & \text { otherwise }\end{cases}
$$$$
\delta *_{j \mathrm{t}}=\mathbf{w}_{\mathbf{j t}} \alpha+\varepsilon_{\mathrm{jt}} .
$$

Equation (1) is the macroeconomic performance equation, where $\mathrm{y}_{\mathrm{j} t}$ stands for each of the macroeconomic outcome variables of interest in country $\mathbf{j}$ and period $\mathbf{t} ; \mathbf{x}_{\mathbf{j}} \mathbf{t}$ is a vector of covariates that capture the role of traditional determinants of economic performance; $\delta$ $\mathrm{jt}$ is a dummy variable (i.e. the treatment variable) that takes a value of one if country $\mathrm{j}$ in period t is "common currency" country, and zero if the country has a currency of its own. Accordingly, $\gamma$ is the parameter of interest: the effect of the treatment on the outcome. The decision to have a common currency is assumed to be the result of an unobserved latent variable $\delta^{*}{ }_{\mathrm{j}}$, described in equation (2). $\delta^{*}{ }_{\mathrm{j}}$, in turn, is assumed to depend linearly on vector $\mathbf{w}_{\mathbf{j}} \mathbf{~}$. Some of the variables in $\mathbf{w}_{\mathbf{j}} \mathbf{t}$ may be included in $\mathbf{x}_{\mathbf{j}} \mathbf{t}$ (Maddala 1983, $\mathbf{p}$. 120). ${ }^{18} \beta$ and $\alpha$ are parameters to be estimated. $\mu_{\mathrm{jt}}$ and $\varepsilon_{\mathrm{jt}}$ are error terms assumed to be bivariate normal, with a zero mean and a covariance matrix given by:

$$
\left(\begin{array}{ll}
\sigma & \varsigma \\
\varsigma & 1
\end{array}\right)
$$

If the performance and common currency equations are independent, the covariance term $\varsigma$ in equation (4) will be zero. Under most plausible conditions, however, it is likely that this covariance term will be different from zero.

Greene (2000) has shown that if equation (1) is estimated by least squares, the treatment effect will be overestimated. Traditionally, this problem has been tackled by estimating the model using a two-step procedure (Maddala 1983). In the first step, the

\footnotetext{
18 It is assumed, however, that $\delta *_{\mathrm{jt}}$ does not depend on $\mathrm{y}_{\mathrm{j} t}$. Otherwise, as discussed below, the model cannot be identified.
} 
treatment equation (2) is estimated using probit regressions. From this estimation a hazard is obtained for each $\mathrm{j} t$ observation. In the second step, the outcome equation (1) is estimated with the hazard added as an additional covariate. From the residuals of this augmented outcome regression, it is possible to compute consistent estimates of the variance-covariance matrix (4). Instead of the traditional two-stage method, in this paper we use a more efficient maximum likelihood procedure to estimate the model in equations (1) through (4) jointly. ${ }^{19}$ As shown by Greene (2000), the log likelihood for observation $\mathrm{k}$ is given by equations (5) and (5'):

$$
\begin{aligned}
& L_{k}=\log \Phi\left\{\frac{w_{k} \alpha+\left(y_{k}-x_{k} \beta-\delta\right) \varsigma / \sigma}{\sqrt{1-\varsigma^{2}}}\right\}-\frac{1}{2}\left\{\frac{y_{k}-x_{k} \beta-\delta}{\sigma}\right\}^{2}-\log \sqrt{2 \pi} \sigma, \\
& \text { if } \delta_{k}=1 \\
& L_{k}=\log \Phi\left\{\frac{-w_{k} \alpha-\left(y_{k}-x_{k} \beta\right) \varsigma / \sigma}{\sqrt{1-\varsigma^{2}}}\right\}-\frac{1}{2}\left\{\frac{y_{k}-x_{k} \beta}{\sigma}\right\}^{2}-\log \sqrt{2 \pi} \sigma, \\
& \text { if } \delta_{k}=0 .
\end{aligned}
$$

The model in equations (1) - (4) will satisfy the consistency and identifying conditions of mixed models with latent variables if the outcome variable $y_{j t}$ is not a determinant (directly or indirectly) of the treatment equation -- that is, if y is not one of the variables in $w$ in equation (3). ${ }^{20}$ For the cases of per capita GDP growth and volatility this is a reasonable assumption. Although the level of GDP per capita may affect the probability of having a common currency, its rate of change, or the second moment of its rate of change is unlikely to have an impact on the decision of having a domestic currency. This consistency and identifying restriction is also met in the case of the inflation model. Indeed, in every one of the countries in our sample, the decision to use a common currency can be traced historically to variables that are structural in nature, including the country's size and its cultural and political relation with the anchor country. Moreover, what may affect the decision of being dollarized is the propensity to have a

19 The two-steps estimates yield similar results, and are available from the authors on request. 
high inflation rate. This propensity, however, is indeed captured by some of the variables in the $\boldsymbol{w}_{\boldsymbol{j} t}$ vector in equation (3). However, in order to check for the robustness of the results obtained from the estimation of the model in equations (1) through (5), in section $\mathrm{V}$ we present results obtained from the instrumental variables estimation of a treatment effects model for inflation.

In the estimation of the model (1)-(5) we also impose some exclusionary restrictions; that is, a number of the $\boldsymbol{w}_{\boldsymbol{j} t}$ covariates included in equation (3), are not included in the outcome equation (1). These exclusionary restrictions are not required for identification of the parameters, but they are generally recommended as a way of addressing issues of collinearity. ${ }^{21}$

\section{III.2 Basic Results for Common Currency Countries as a Group}

In this section we report the results obtained from the estimation of the treatment effects model given by equations (1) through (4). The "treatment group" is defined as all countries without a currency of their own. That is, the dummy variable $\delta_{\mathrm{tj}}$ takes a value of one if in period t country $j$ does not have a domestic currency; no distinction is made, at this point, between strictly dollarized and ICU countries - see, however, the results in section IV. The data set covers 1970 through 1998, and includes 199 counties and territories. The number of observations varies, depending on the outcome variable considered. There are 3,122 observations on inflation and 5,233 observations on growth per capita. When using 5 years averages - both in the growth and volatility models - the panel has 950 observations. $^{22}$

\section{III.2.1 The Treatment Equation}

In a highly influential article, Mundell (1961, p. 181) argued that the "optimum currency area is the region." By this he meant that regional considerations geographical proximity and the existence of factor mobility, among other - were more important than national (or sovereign) considerations in determining optimal currency areas. This regional-based approach has been present in most subsequent work on the

\footnotetext{
${ }^{20}$ Details on identification and consistency of models with mixed structures can be found in Maddala (1983). See, also, Heckman (1978), Angrist (2000) and Wooldridge (2002).

${ }^{21}$ Wooldridge (2002).

22 Remember that the volatility variable is measured as the standard deviation of growth over a five year period. When alternative 7-year periods were used, there were no significant changes in the results.
} 
subject of optimal currency areas. ${ }^{23}$ Following Mundell's insight, we include a number of "regional variables" in our empirical analysis on the probability of being a "common currency" country. More specifically, in the specification of the treatment equation (3), we included the following covariates that encapsulate the importance of the "region:" (a) a dummy variable that takes the value of one if the economy in question is an independent nation, and zero if it is a territory. Since factor mobility is much lower across independent nations than between a dependent territory and the "home country", we expect the coefficient of this variable to be negative in the estimation of equation (3). (b) A dummy variable that takes the value of one if the country in question is an island or archipelago. Since island-archipelago countries are relatively isolated, they tend to be self-contained regions. We expect this variable to have a negative coefficient in (3). And (c), a dummy variable that takes the value of one if the country has a common border with a nation whose currency is defined, by the IMF, as a "convertible currency." We call this variable "border," and we expect its estimated coefficient to have a positive sign in equation (3). In addition to these regional variables ${ }^{24}$, the following covariates were also included in the specification of the treatment equation (3): (d) the log of population measured in millions of people, as an index of the country's size. We expect the estimated coefficient of this variable to be negative, indicating that larger countries are less likely to use another nation's currency. (e) The log of initial (1970) GDP, taken as a measure of the country's economic size. We also expect the coefficient of this variable to be negative. (d) An indicator of the degree of openness of the economy. For the majority of countries and years we used the Sachs and Warner (1995) openness index. We used data from a variety of sources to supplement the Sachs-Warner index for those countries and years not covered in their sample. ${ }^{25}$ As Frieden (2003) has argued, its estimated coefficient is expected to be positive. And, (g) a variable that measures the (log of the) distance between each country and global markets; in defining this "distance variable" we followed Leamer (1999). We expect its estimated coefficient to be positive indicating

\footnotetext{
${ }^{23}$ See Alesina, Barro and Tenreyro (2002) for a recent discussion on the subject.

${ }^{24}$ Unfortunately, there are no available data on other regional variables of interest, including a generalized index of factor mobility or of synchronicity of shocks, for all countries in our sample.

25 See the original Sachs-Werner (1995) article for a specific list of requirements for a country to qualify as "open."
} 
that countries that are less integrated to world markets will have a lower probability of being common currency countries.

\section{III.2.2 The Outcome Equations}

We specified (and estimated) three different models, for (a) GDP per capita growth, (b) inflation, and (c) growth volatility. A difficulty we faced in undertaking this analysis is that many "common currency" countries have limited data availability. For instance, very few of the strictly dollarized countries have data on education attainment or on some other variables traditionally included in growth empirical analyses (Barro and Sala-I-Martin 1995, Barro, 1996). Indeed, popular data sets, such as the World Bank WDI, the IFS or the Barro-Lee (1996) data set, include data on only a handful - three or four - strictly dollarized countries. Nevertheless, and after searching in a number of alternative data sources, we were been able to include a number of covariates in the outcome equations (1) for per capita growth, inflation and volatility. ${ }^{26}$

In the estimation of the GDP growth model we included, as customary, initial GDP, a measure of openness, a variable that captures the country's geographical location, regional dummies (no dummies were included for Asia, which is defined as the reference region), ${ }^{27}$ and the "common currency" dummy. As Sachs (2000), among others, has argued, countries located close to the equator tend to grow more slowly, after controlling for other factors, than nations in other parts of the world. Our geography variable -which we call "tropics"-- is defined as the (normalized) absolute distance from each country to the equator. We expect its coefficient to be negative, capturing the fact that, with other things constant, countries closer to the tropics will tend to grow at a slower rate than countries in other geographical areas. ${ }^{28}$

In the inflation model, in addition to the common currency dummy, we included openness, lagged inflation (as a measure of persistence), inflation lagged twice, the tropics geography variable, distance and the regional dummies. Finally, in the volatility model we include the following covariates in the outcome equation: initial GDP, openness, the regional dummies and the common currency dummy. As in the other

\footnotetext{
26 The data are available from the authors on request.

27 These variables are expected to capture the effect of some of variables for which there were no data.

${ }^{28}$ See Leamer (1997) and Venables (2002) for discussions on the role of geography and distance on economic growth.
} 
models, in some of the specifications we introduced regional variables. In the volatility model we expect that the estimated coefficient of both openness and initial GDP will be negative.

\section{III.2.3 Results}

In Table 3 we summarize the results obtained from the estimation of the treatment effects model for GDP per capita growth. Table 4 contains the results for inflation, and Table 5 those for growth volatility. Each of these tables contains two panels. The upper panel includes the results from the outcome equation; the lower panel contains the estimates for the "treatment equation."

Probability of Being a Common Currency Country: As may be seen from these tables, the results are similar across models and are quite satisfactory. The vast majority of the coefficients have the expected signs and are statistically significant at conventional levels. They clearly indicate that the probability of being a "common currency" country is higher for very small, not independent countries (or territories). Being an island reduces the probability of having a common currency; as does greater distance from world markets. The estimated coefficient of "border" is not significant at conventional levels and has a negative sign - see, however, the discussion in Section IV. ${ }^{29}$

GDP per Capita Growth: In Table 3 we present the results obtained from the estimation of the growth model. We report results from six systems: the first three were estimated using annual data, while the last three were estimated using five year averages. As may be seen, the traditional regressors have the expected signs and are significant at conventional levels. In terms of the monetary regime, these results show that the coefficient of the "common currency" dummy is positive and statistically significant for all specifications. Its point estimate ranges from 0.749 to 1.204 . This suggests that, during the period under consideration, and after controlling for other factors, countries with a "common currency" regime experienced a higher rate of growth of GDP per capita than countries with a currency of their own. These results suggest that the growth advantage of "common currencies" countries amounted, on average, to approximately 1

\footnotetext{
${ }^{29}$ In addition to the variables in tables 3-6, we considered additional covariates. In particular, we constructed an index on whether the country in question was a member of a "deep" trading area. This index, however, identifies almost fully the "common currency" countries, reducing the spirit of the analysis.
} 
percentage point per year. Notice that these results are quite different from the simple means differences reported in Table 2: while according to those results there have been no differences in average rates of growth across the two groups of countries, the estimates in Table 3 indicate that common currency countries have grown at a significantly faster rate than countries with a currency of their own. The chi square test for the independence of the treatment and outcome equations indicates that in all specifications the null hypothesis of independence across the equations is rejected at conventional levels. ${ }^{30}$

Inflation: The results for the inflation model are reported in Table 4. As may be seen from the "outcome" equation in the upper panel, the "common currency" dummy is negative and significant in every one of the specifications. The point estimates range from -11.99 to -14.43 , not only confirming that inflation has historically been lower in the "common currency" countries, but also indicating that the "common currency" advantage is somewhat larger than what the simple mean differences results reported in Table 2 suggest. The other covariates in the inflation regressions reported in table 4 have the expected signs, and are statistically significant. In particular, these results indicate that more open countries have lower inflation, as do countries that are geographically closer to the global markets. Inflation appears to have some degree of persistence, and the regional dummies indicate that, relative to the benchmark (Asia), Latin America and Africa have had a significantly higher rate of inflation. As the $\chi^{2}$ statistics show, the null hypothesis of independent equations is rejected at conventional levels. In order to investigate the robustness of these results, and to deal with potential endogeneity problems, we also estimated the inflation model using an instrumental variables treatment approach. The results are presented in Section V.

Volatility: Table 5 contains the results for the volatility models. The null hypothesis of independent equations is rejected at conventional levels -- the $\chi^{2}$ statistics range from 29.0 to 34.7 - and the dummy variables for "common currency" are significantly positive, indicating that countries without a domestic currency have experienced a higher degree of growth volatility than countries with a currency of their

\footnotetext{
${ }^{30}$ An important question is whether these results - as well as those in tables 4-5 - are subject to an "omitted variables" bias, stemming from the fact that there are no data on some of the traditional regressors
} 
own. Openness reduces volatility $-\mathrm{a}$ result that is in line with a number of theoretical results in international economics. ${ }^{31}$ In addition, our estimates indicate that, after controlling by other factors, countries that are closer to the equator have exhibited a higher degree of volatility. Also, countries with a higher initial level of GDP per capita have had a somewhat higher degree of volatility (the point estimate of this coefficient is, however, rather low). According to these results, growth in the countries of North Africa and the Middle East (MENA) has been particularly volatile. In what appears to be a counterintuitive result, the coefficient for the Europe dummy is positive, although not significant. The reason for this apparent anomaly is that that the Eastern and Central European nations are part of the World Bank European region. Finally, notice that the estimated coefficients for the "common currency" dummy are significantly larger than the "unadjusted" mean differences in volatility presented in Table 2.

\section{Strict Dollarization and Independent Currency Unions: Is There a Difference?}

The results reported in the preceding section grouped all "common currency" countries together, implicitly assuming that strict dollarization and ICU are equivalent monetary regimes. This, however, needs not be the case. As was argued in Section I above, there are a number of differences between them, in terms of independence of monetary policy, seignorage revenue, and capacity to absorb external shocks. In this section we break up the "common currency" countries into "strictly dollarized" countries and ICUs. We then estimate treatment effects models for GDP growth, inflation and volatility for each of these two groups separately. ${ }^{32}$ The specification of both the treatment and outcome equations are similar to those reported in tables 3-5 for the "common currency" nations.

The results for GDP growth are in Table 6. Those for inflation are in Table 7 and those on volatility are in Table 8 . In each of these Tables we report a limited number of equations. The results for alternative specifications were similar, and are available on request. An inspection of the results suggest the following patterns:

for the common currency countries. We address this issue in some detail in Section IV of this paper.

31 See Frenkel and Razin (1987). 
- There are important differences in the results for the treatment equation for ICU and strictly dollarized countries. More specifically, the results for the probability of not having a domestic currency differ in the following respects for these two samples: First, while the coefficient of "border" is positive (and significant at either the 5 or 10 percent level) in the "strict dollarization" models in Table 7 (Models 1 and 3), it is significantly negative in the estimates for the ICU countries (Table 7, Models 2 and 4). This indicates that geographical proximity to a "convertible" currency nation is only important in determining the probability of being a dollarized country. Second, the coefficient for openness is significantly positive, as expected, in the dollarized models (Table 7); it is negative in the ICU models. As we argue in Section V below, the CAF countries largely drive this result. These important differences in the probit results support the hypothesis that it is not correct to consider - as most authors have done until now - the two type of common currency regimes as a homogeneous group.

- In the GDP growth models, the dummy for "strict dollarization" is never significant, indicating that after controlling for simultaneity and other factors, there is no discernible difference in growth performance between dollarized countries and countries with a currency of their own.

- In the GDP growth models, the dummy for "ICUs" is significantly positive, with a point estimate ranging from 1.36 to 2.72 . This suggests that, with other things given, independent currency union countries have grown at a significantlyfaster rate than countries with a currency of their own. Moreover, according to our point estimates the growth effect of an ICU monetary regime appears to have been quite large.

- In the inflation models the dummies for both the "strictly dollarized" and the "ICU" countries are significantly negative, confirming that both type

32 In doing this we excluded the other "common currency" group from the "with-domestic-currency" sample. That is, the "with-domestic-currency" is strictly made of countries that do have a currency of their own. 
of common currency countries have been able to have a significantly lower rate of inflation than the with-domestic-currency countries.

- In the inflation models the point estimates for the dummies are quite different for the two groups of countries. In fact, these results suggest that the "low-inflation" advantage is greater for the ICU countries. This contrasts with the "unadjusted" comparisons reported in table 2, which suggested that strictly dollarized countries had a lower average inflation rate than ICU countries.

- The results for the volatility model show that the dummies' coefficients are significantly positive for both groups of countries. This supports the idea that super hard peg countries regimes tend to result in higher real volatility.

\section{Robustness Analysis and Further Results}

In this section we deal with some extensions, we investigate the robustness of the results, we address with potential endogeneity problems in the inflation equation, and we inquire on what is behind the results reported above.

\section{V.1 Non-Parametric Methods}

It is possible that the specification forms chosen for the outcome equations affect the results reported above. In particular, the linearity of these equations may affect the estimates of the "treatment coefficient." In order to investigate whether this is an important factor, we undertook a non-parametric analysis based on "matching estimators" (see Blundell and Costa-Dias 2000). A general advantage of this non-parametric method is that no particular specification of the underlying model has to be assumed. Matching estimators pair each common currency country with countries from the with-domesticcurrency group. ${ }^{33}$ If the sample is large enough, for each treated (common currency) observation we can find, in principle, at least one untreated observation with exactly the same characteristics. Each of these properly selected untreated observations provides the

\footnotetext{
${ }^{33}$ If we estimate the equation above using all non-treated observations the selection bias is given by: $B(x)=E\left(u_{0} / x, D=1\right)-E\left(u_{0} / x, D=0\right)$.
} 
required counterfactual for our comparative analysis. ${ }^{34}$ The problem is that under most general conditions it is not possible to find an exact match between a treated and untreated observation. The matching estimator method focuses on estimating an average version of the parameter of interest. ${ }^{35}$ That is, the matching estimator consists of obtaining the difference in outcome as an average of the differences with respect to “similar" -- rather than identical -- untreated outcomes. Rosenbaum and Rubin (1983) have shown that an efficient and simple way to perform this comparison is to rely on a propensity score, defined as the probability of participation or treatment: $P(x)=\operatorname{Prob}(D=1 / x)$. In our case, this is the probability of a country being a common currency country. This reduces a multi-dimensional problem to a one-dimensional problem, provided that we can estimate $P(x)$. Instead of matching countries directly on all of their characteristics, we can compare countries with similar probability of being a common currency country. An additional advantage of this method is that the estimation of the treatment on the treated, is not affected by the lack of data on some of the other variables affecting the outcome. In that regard, then, this method provides us with an elegant way of handling potential problems emanating from omitted variables in the outcome equations. $^{36}$

In this section we report results obtained from using a simple-average nearest neighbor estimator. According to this method, for each treated observation, we select a pre-determined number of untreated nearest neighbor(s). The nearest neighbors of a particular treated observation $i$ are defined as those untreated observations that have the smallest difference in propensity score with respect to $i$. If we choose to use $n n$ nearest

\footnotetext{
${ }^{34}$ In order to guarantee that all treated agents have such a counterpart in the population (not necessarily in the sample) we also need to assume that $0<\operatorname{Pr} o b(D=1 / x)<1$.

${ }^{35}$ This averaged version is given by:

$M(S)=\frac{\int_{S} E\left(y_{1}-y_{0} / x, D=1\right) d F(x / D=1)}{\int_{S} d F(x / D=1)}$,
}

where $\mathrm{S}$ is a subset of the support of $x$ given $D=1$.

36 This assumes that there are no omitted variables problems in the estimation of the propensity used to select the nearest neighbors. 
neighbors, we set $W_{i j}=\frac{1}{n n}$ for the observations that have been selected; for other observations we set $W_{i j}=0$. We applied the above method to both one nearest neighbor and five nearest neighbors.

The results we report in Table 9 were obtained using a "multiple treatments" procedure that assumes that at any point in time there are two possible (and alternative) "treatments:" (a) a dollarization treatment, and (b) an ICU treatment. The untreated group is comprised of all those countries with a currency of their own. ${ }^{37}$ The matching results in Table 9 may be summarized as follows: First, we confirm that both type of hard peg monetary regimes have resulted in lower inflation than regimes with a domestic currency. Second, the GDP growth estimates confirm that ICU countries have grown at a faster rate than countries with a currency of their own; the opposite is the case for dollarized countries. In fact, these results indicate that countries with a dollarized regime have grown at a significantly lower rate than countries with a domestic currency. This result contrasts with the regression results reported in Table 7, which suggested that there had been no difference in the rates of growth in the two groups. And third, the estimates for volatility indicate that in both hard peg regimes it has been higher than in countries with a currency of their own. These mean differences are only significant when five nearest neighbors are used.

Overall, we interpret the results from the matching exercise as providing broad support to the findings reported in the preceding section: countries with both hard peg regimes have had lower inflation than countries with a currency; only ICU countries have had higher growth; and both hard pegs appear to have had a more volatile real economy than countries with a domestic currency.

\section{V.2 Redefining "Very Rapid Inflation"}

In our inflationary analysis we excluded countries with extremely rapid inflation, or "hyperinflation countries." In the estimates reported in tables 4 and 7 the sample excluded countries with a rate of inflation in excess of $200 \%$ per year It is possible, however, that by still allowing highly inflationary countries in the sample, the estimates

${ }^{37}$ See Lechner (2002) for a discussion on matching methods with multiple treatments. The results in Table XXX correspond to the case when "no replacement" is allowed in selecting the nearest neighbors in the control group. See Edwards and Magendzo $(2003,2002)$ for details. 
obtained are being driven by extreme or outlier observations. In order to investigate this issue we re-estimated the inflationary equation under alternative definitions of "extremely rapid inflation." More specifically, in the alternative estimates we first excluded observations with an annual rate of inflation in excess of $100 \%$; we then repeated the exercise excluding observations with inflation in excess of $50 \%$ per year.

The results obtained when these new samples were used confirmed those reported above, in the sense that inflation is significantly lower in common currency countries. Interestingly, however, under these new definitions of very rapid inflations the stability advantage of ICU countries appear to be even greater than that reported in section IV.

\section{V.3 Instrumental Variables Estimation of the Inflation Model}

The results presented in the preceding sections assumed that the treatment did not depend on the outcome variable. ${ }^{38}$ That is, in estimating the treatment models in Sections III and IV we assumed that the treatment (common currency) dummy was a strictly exogenous variable. It is possible to argue that this assumption is not valid in the inflation model; according to this line of argument, countries that choose a common currency regime are countries with high inflation rates. In order to deal with this possible source of bias, we also estimated the inflation model using an instrumental variables (IV) version of the treatment approach.

Under general conditions the outcome equation (1) can be re-written as:

$$
\mathrm{y}=\alpha+\gamma \delta+\mathbf{x} \beta_{0}+\delta(\mathrm{x}-\mathrm{E}(\mathrm{x})) \beta_{1}+\mathrm{e}_{0}+\delta\left(\mathrm{e}_{1}-\mathrm{e}_{0}\right)
$$

where the subscript indicates the value of $\delta$ and $\mathrm{e}_{0}$ and $\mathrm{e}_{1}$ are zero mean, normally distributed error terms, conditional on $\mathrm{X}$ and a set of instruments $\mathrm{Z}$. We assume that the treatment depends on the instruments $Z$, that is, that the vector $w$ in equation (3) contains variables that are excluded from the outcome equation and that are orthogonal to the error terms. Woodridge (2002) shows that a consistent estimator of $\gamma$, even when $\delta$ is endogenous, is obtained by a two-step procedure. In the first step we estimate the parameters in equation (3) using a probit regression of $\delta$ on $\mathrm{X}$ and $\mathrm{Z}$; from this estimation we then obtain the hazard for each observation. In the second step we estimate the 
parameters in ( $\left.1^{\prime}\right)$ by OLS including the dummy variable, the variables in $X$, the hazard function and the interaction of the dummy variable with $X-E(X)$, where we use the sample average of $X$ as an estimate of the expected value. The hazard --estimated using the instruments Z-- together with the interaction terms play the role of a control function that control for possible selection bias ${ }^{39}$.

In the estimation of (1') for inflation, the following instruments were used: log of population, log of initial GDP, an independent dummy, an index of the degree of openness, the "tropics" variable, the regional dummies, the log of distance, the "border" variable, the "island" variable, and the average of inflation in the five years prior to our first data point. The results obtained from this IV treatment model confirm those presented in Sections III and IV above. More specifically, the point estimate of the dummy for strict dollarization is -12.9 and was significant. The dummy for the ICU was also significant and its point estimate was -18.8 . The detailed results from these IV treatment estimates - not reported here due to space consideration - are available from us on request.

\section{V.4 What is Really Behind these Results? The Role of the CFA and the ECCA}

From a policy perspective - and in particular from a "lessons" point of view -- an interesting question is whether a specific group of countries is behind the results reported in the preceding sections. We are particularly interested in understanding whether there is any pattern behind the results suggesting that, while strictly dollarized countries have grown at a rate similar to those countries with a currency of their own, ICU countries have grown significantly faster than nations with a domestic currency. In order to investigate this issue we analyzed the residuals from our regression analysis, and inquired on the characteristics of our ICU data set.

As may be seen from Table 1, the ICU data set maybe divided into three groups of countries: seven members of the East Caribbean Currency Association (ECCA), fifteen members from the CFA Franc Zone in Africa, and countries from different parts of the world. A detailed inspection at the raw data suggests that there are very substantial differences in terms of economic growth between the ECCA nations, on the one hand,

38 This assumption is sometimes referred as the "ignorability-of -treatment assumption." Wooldridge (2002).

${ }^{39}$ For details on these procedures see Woodridge (2002). 
and the rest of the ICU countries. Indeed, for the period under consideration average yearly GDP per capita growth in the ECCA countries has been 3.16\%. In the other ICU countries, on the other hand, it has only been $0.79 \%$. The comparison of medians yields a similar result, with the median growth for ECCA countries at 3.6\%, and that for the rest of the ICUs at $0.72 \%$. This unconditional comparison suggests that the ECCA nations' performance is behind our findings (Table 6) that, with other things given, ICU nations grow at a faster rate than countries with a domestic currency. In order to investigate this, we estimated separate treatment effects model for GDP per capita growth for ECCA and other-ICU nations. ${ }^{40}$ The estimated coefficient for the ECCA common currency dummy variable was 2.3 , with a t-statistics of 4.46 , confirming that ECCA nations have outperformed by a wide margin countries with a currency of their own. The results for the non-ECCA ICU countries were quite different, with a statistically insignificant estimated coefficient for the treatment dummy of $0.5{ }^{41}$ These results, then, confirm the notion that the driving force behind the apparent superior growth performance of common currency countries, reported in the preceding sections, is fully driven by the group of seven ECCA nations.

\section{Concluding Remarks}

In the aftermath of the currency crises of the 1990s a number of economists have argued that the emerging economies should give up their domestic currencies. Interestingly, there have been very few systematic comparative studies on the performance of countries that, indeed, do not have a currency of their own. Moreover, there has been no effort in the empirical literature to make a distinction between "strictly dollarized" countries and "independent currency union" countries. Most of the literature on the subject has, in fact, been based on case studies of Panama, or on indirect performance analyses of groups of countries strongly dominated by ICUs. This lack of empirical analyses has resulted in policy debates that, until now, have been based on conjectures and not on hard historical evidence. This has been particularly the case when the issue under discussion relate to the merits of "strict dollarization."

\footnotetext{
40 In the estimation we had to re-specify the treatment equation. The reason is that some of the regressors (islands, for example) fully predicted the probability of being a currency union country.

${ }_{41}$ These results are from a specification that includes regional dummies in the GDP growth outcome equation. If these dummies are excluded the ICU dummy becomes negative with a t-statistic of -1.46 .
} 
The purpose of this paper has been to analyze, from a comparative perspective, economic performance in economies that don't have a currency of their own. We have argued that the main difficulty in performing this type of comparison refers to defining the correct "control group" with which to compare the performance of the dollarized countries. In this paper we tackled this issue by using the "treatment effects model" developed in the labor economics literature; this method allows us to jointly estimate the probability of being a "common currency country," and the effect of having this particular monetary regime on specific macroeconomic outcomes. Estimation using this technique yields results that are substantially different from those obtained from simple comparisons using a large control group of all with-domestic-currency countries. More specifically, we found that both ICU and dollarized countries have had a significantly lower rate of inflation than with-currency ones. We found that macroeconomic volatility has been higher in both dollarized and ICU economies, than in with-currency countries.

We believe that our results are particularly interesting with respect to GDP growth. The estimations reported in Table 6 suggest that while strictly dollarized countries have had a statistically rate of GDP per capita growth that is not different from that of countries with a currency of their own, ICU countries have grown faster than with currency nations. When we investigated these findings further, we found that the East Caribbean Currency Area countries were the driving force behind this estimated ICUs superior growth performance. Indeed, once these seven countries were excluded from the sample, we found no statistical difference in GDP per capita growth in the rest of the ICU countries and countries with a currency of their own. The ECCA countries constitute, indeed, a very special group: They are very small indeed, with an average population of less than 100,000 inhabitants. They are all islands, geographically close to major markets. Their main industry is tourism, and they have very close economic and cultural ties with the United Kingdom. We believe that their experience with ICU may not be entirely useful for larger countries planning to reform their exchange rate and monetary regime. This does not mean, however, that other emerging nations would not benefit from giving up their currencies. Indeed, as Mundell (1961) argued four decades ago, it is perfectly possible that countries with certain characteristics will benefit from giving up their currency and either dollarizing or joining a currency union. In that regard the 
experiences of Ecuador and El Salvador -- two recent dollarizers -- will be very useful to assess this question in the future. Naturally, the euro experience will provide a wealth of information on the consequences of common currencies in advanced nations. 


\section{REFERENCES}

Alesina, A. and R.J Barro (2000), “Currency Unions”, NBER Working Paper 7927.

Alesina, A. and R.J Barro (2000), “One Country, One Currency?” in A. Alesina and R.J Barro (eds.) Currency Unions, Hoover Institution Press Publication.

Alesina, A. and R.J. Barro (2001). “Dollarization”, American Economic Review; 91(2), 381-85.

Alesina, A., R.J. Barro and S. Tenreyro (2002). "Optimal Currency Areas" NBER Working Paper 9072.

Angrist, J. (2000). "Estimation of Limited Dependfent Variable Models with Dummy Endogenous regressors: Simple Strategies for Empirical Practice,” NBER TP \# 248.

Barret, L. (1995). “The Economic Trials of Liberia,” West Africa, 461-463

Barro, R.J. (1996). "Determinants of Economic Growth: A Cross-Country Empirical Study”, NBER Working Paper 5698.

Barro, R.J. and Lee, J. (1996). "International Data on Educational Attainment: Updates and Implications", CID Working Paper 42.

Baro, R.J. and X. Sala-i-Martin (1995). Economic Growth, McGraw Hill

Berkeley, B. (1993). “Liberia’s Warring Currencies”, Institutional Investors.

Blundell, R., A and Costa Dias, M. (2000), "Evaluation Methods for Non-Experimental data," Fiscal Studies, 21, 427-468.

Bogetic, Z. (2000). “Official Dollarization: Current Experiences and Issues”, Cato Journal; 20(2), 179-213.

Calvo, G.A. (1999). "Fixed vs. Flexible Exchange Rates,” U. of Maryland Working Paper

Cooper, R.W. and H. Kempf (2001). "Dollarization and the Conquest of Hyperinflation in Divided Societies”, Federal Reserve Bank of Minneapolis Quarterly Review 25(3).

Corden W.M. (2002). Too Sensational: On the Selection of the Exchange Rate Regime, MIT Press

Dornbusch, R. (2001). "Fewer Monies, Better Monies", American Economic Review; 91(2), 238-42. 
Edwards, S. (1999). "Exchange Rate Regimes, Capital Flows and Crisis Prevention," Presented at the NBER Conference on Capital Flows and Currency Crises

Edwards, S. (2001). "Dollarization: Myths and Realities", Journal of Policy Modeling 23(3), 249-65.

Edwards, S. and I.I. Magendzo (2002). "Dollarization, Inflation and Growth" ", NBER Working Paper, No 8671.

Edwards, S. and I.I. Magendzo (2003). "Strict Dollarization And Economic Performance," Working Paper, UCLA

Eichengreen, B. (2001). "What Problems Can Dollarization Solve?", Journal of Policy Modeling 23(3), 267-77.

Eichengreen, B. and R. Haussmann (1999). "Exchange Rates and financial Fragility", paper presented at the IDB-OECD forum.

Fischer, S. (1976). "Stability and Exchange Rate Systems in a Monetarist Model of the balance of payments," in R.,Z. Aliber, The Political Economy of Monetary Reform, McMillan, New York

Fischer, S. (2001). “Exchange Rate Regimes: Is the Bipolar View Correct?”, Journal of Economic Perspectives; 15(2), 3-24.

Frankel, J.A. (1999); "No Single Currency Regime is Right for All Countries at at All Times", National Bureau of Economic Research Working Paper: 7338.

Frankel, J.A. and A.K. Rose (2002). "An Estimate of the Effect of Common Currencies on Trade and Income", Quarterly Journal of Economics, 117(2).

Frenkel, J.A. and A. Razin (1987). Fiscal Policies and Growth in the World Economy, MIT Press

Frieden, J. (2003). "The Political Economy of Dollarization" in E. Levy-Yeyati and F. Sturzenegger (Eds.) Dollarization, MIT Press

Ghosh, A., A. Gulde, J. Ostry and H. Wolf, (1995). "Does the Nominal Exchange Rate Regime Matter?" IMF Working Paper 95/121.

Goldfajn, I. and G. Olivares (2000). "Is Adopting Full Dollarization the Solution? Looking at the evidence", PUC-Rio Working Paper 416.

Green, W.H. (2000). Econometric Analysis. Macmillan Publishing Company. 
Heckman, J. (1978). "Dummy Endogenous Variables in a simultaneous Equation System”, Econometrica 46.

Heckman, J.J., I. Hidehiko and P.E. Todd (1997). "Matching as an Econometric Evaluation Estimator: Evidence from Evaluating a Job Training Programme", Review of Economic Studies 64(4).

IMF (1997). "Exchange Rate Arrangements and Economic Performance in Developing Countries" Ch. 4 of World Economic Outlook, October.

Klein, M.W. (2002). "Dollarization and Trade”, NBER Working Paper 8879.

Leamer, E.E. (1997). "Access to Western Markets and Eastern Effort," in Salvatore Zecchini, ed., Lessons from the Economic Transition, Central and Eastern Europe in the 1990s, Dordrecht: Kluwer Academic Publishers, pp. 503-526.

Lechner, M. (2002). "Program Heterogeneity and Propensity Score Matching: An Application to the Evaluation of Active Labor Market Policies", Review of Economics and Statistics, 84(2).

Levy-Yeyeti, E. and F. Sturzenegger (2003). Dollarization, The MIT Press

Levy-Yeyeti, E. and F. Sturzenegger (2001). "To Float or to Trail: Evidence on the Impact of Exchange Rate Regimes", Universidad Torcuato di Tella.

Maddala, G.S. (1983). Limited-Dependant and Qualitative Variables in Econometrics. Cambridge University Press.

Meade, J.E. (1950) The Balance of payments, Oxford University Press

Moreno-Villalaz, J.L. (1999) "Lessons from the Monetary Experience of Panama: A Dollar Economy with Financial Integration”, Cato Journal 18(3), 421-39.

Mundell, R.A. (1961). “A Theory of Optimum Currency Areas”, American Economic Review, 51(3).

Parrado, E. and A. Velasco (2002). "Optimal Interest Rate Policy in a Small Open Economy”, NBER Working Papers 8721.

Powell, A. and F. Sturzenegger (2000), "Dollarization: The Link Between Devaluation and Default Risk." Working Paper, Universidad Torcuato di Tella, Buenos Aires, Argentina

Rose, A. (2000). "One Money, One Market: Estimating The Effect of Common Currencies on Trade", Economic Policy 15(30), 7-46. 
Rose, A.K. and C. Engel (2000). "Currency Unions and International Integration”, NBER Working Paper 7872.

Rose, A.K. and C. Engel (2002). "Currency Unions and International Integration", Journal of Money, Credit, and Banking, 34(4).

Rose, A.K. and E. van-Wincoop (2001). "National Money as a Barrier to International Trade: The Real Case for Currency Union”, American Economic Review; 91(2).

Rosenbaum P.R. and D.B. Rubin (1983), "The Central Role of the Prpensity Score in Observational Studies for Causal Effects”, Biometrika 70.

Sachs, J. and A. Warner (1995) "Economic Reform and the Process of Global Integration," Brookings Papers on Economic Activity, 1, 1-188.

Sachs, J.D. (2000). "Globalization and Patterns of Economic Development", Weltwirtschaftliches Archiv/Review of World Economics 136(4).

Summers, L.H. (2000). "International Financial Crises: Causes, Prevention, and Cures”, American-Economic-Review, 90(2), 1-16.

Venables, A.J., H. Overman and S. redding, (2002). "The Economic Geography of Trade, Production and Income" CEPR

Wooldridge, J.M. (2002). Econometric Analysis of Cross Section and Panel Data. MIT Press 
Table 1: Common Currency Countries With Available Macroeconomics Data

\begin{tabular}{|c|c|c|}
\hline 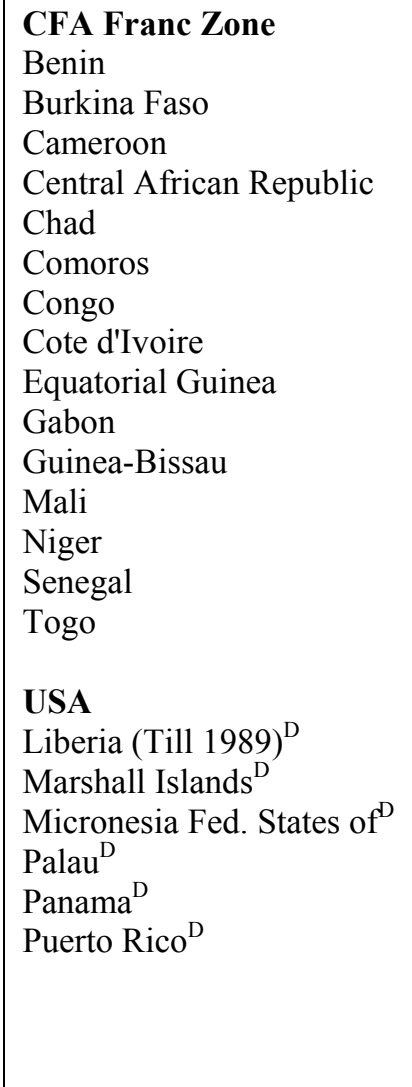 & $\begin{array}{l}\text { FRANCE } \\
\text { Andorra (also Spanish Peseta) }^{\mathrm{D}} \\
\text { French Guiana }^{\mathrm{D}} \\
\text { French Polynesia } \\
\text { Guadeloupe }^{\mathrm{D}} \\
\text { Martinique }^{\mathrm{D}} \\
\text { Monaco }^{\mathrm{D}} \\
\text { New Caledonia } \\
\text { Reunion } \\
\\
\text { ECCA } \\
\text { Antigua and Barbuda } \\
\text { Dominica } \\
\text { Grenada } \\
\text { Montserrat } \\
\text { St. Kitts and Nevis } \\
\text { St. Lucia } \\
\text { St. Vincent and the Grenadines } \\
\text { South Africa } \\
\text { Lesotho } \\
\text { Namibia } \\
\text { Swaziland } \\
\text { New Zealand } \\
\text { Cook Islands }\end{array}$ & $\begin{array}{l}\text { Italy } \\
\text { San Marino }^{\mathrm{D}} \\
\text { Australia } \\
\text { Kiribati }^{\mathrm{D}} \\
\text { Nauru }^{\mathrm{D}} \\
\text { Tuvalu }^{\mathrm{D}} \\
\text { East Africa } \\
\text { Kenya (Till 1979) } \\
\text { Tanzania (Till 1979) } \\
\text { Uganda (Till 1979) } \\
\text { India } \\
\text { Bhutan } \\
\text { Singapore } \\
\text { Brunei } \\
\text { Denmark } \\
\text { Greenland } \\
\text { Switzerland } \\
\text { Liechtenstein } \\
\text { Belgium } \\
\text { Luxembourg }^{\mathrm{D}}\end{array}$ \\
\hline
\end{tabular}


TABLE 2

Inflation, Growth and Volatility in Common Currency Countries and Countries with Domestic Currency

\begin{tabular}{|c|c|c|c|}
\hline & $\begin{array}{c}\text { (A) } \\
\text { Dollarized \& } \\
\text { Union } \\
\text { Countries }^{\mathrm{a}} \\
\end{array}$ & $\begin{array}{c}\text { (B) } \\
\text { Other } \\
\text { Countries }\end{array}$ & $\begin{array}{c}(C) \\
\text { Difference * } \\
(A)-(B)\end{array}$ \\
\hline \multicolumn{4}{|c|}{ A. All Common Currency Countries versus Control Group } \\
\hline \multicolumn{4}{|c|}{ A. Inflation } \\
\hline Mean & 7.26 & 16.20 & $\begin{array}{c}-8.94 \\
(-10.13)\end{array}$ \\
\hline Median & 5.30 & 9.03 & $\begin{array}{c}-3.73 \\
(-11.38)\end{array}$ \\
\hline \multicolumn{4}{|c|}{ B. Per capita GDP growth } \\
\hline Mean & 1.29 & 1.19 & $\begin{array}{c}0.10 \\
(0.48)\end{array}$ \\
\hline Median & 1.29 & 1.90 & $\begin{array}{c}-0.61 \\
(-4.01)\end{array}$ \\
\hline \multicolumn{4}{|c|}{ C. Volatility of Growth } \\
\hline Mean & 4.74 & 4.17 & $\begin{array}{c}0.57 \\
(1.91)\end{array}$ \\
\hline Median & 3.48 & 2.89 & $\begin{array}{c}0.59 \\
(2.67)\end{array}$ \\
\hline
\end{tabular}

\section{B. Strictly Dollarized versus Control Group}

A. Inflation

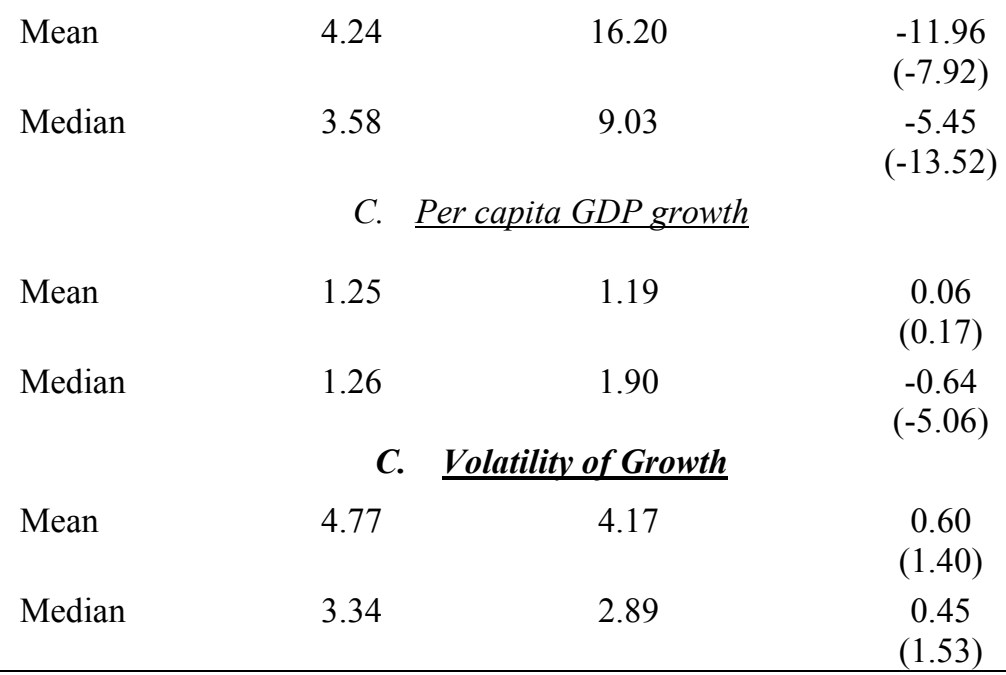

a: Number of observations with data for inflation is 760, of which 249 are strictly dollarized and 511 belong to an ICU. There are 1,332 observations with data for per capita growth, of which 526 belong to strictly dollarized country and 806 to an ICU.

b: Number of observations with data on inflation is 2,732 and there are 3,907 observations with data for per capita GDP growth.

*: Number in parentheses are t-statistics 
TABLE 2 (cont.)

$\underline{\text { Inflation, Growth and Volatility }}$

\section{ICUs versus Control Group}

(A) Monetary Unions $^{\mathrm{a}}$
(B)

Other Countries $^{\text {b }}$
(C) Difference *

(A) - (B)

\section{A. Inflation}

\begin{tabular}{|c|c|c|c|}
\hline Mean & 8.73 & 16.20 & $\begin{array}{c}-7.47 \\
(-6.95)\end{array}$ \\
\hline Median & $\begin{array}{r}6.94 \\
B .\end{array}$ & $\begin{array}{r}9.03 \\
G D P g r\end{array}$ & $\begin{array}{c}-2.09 \\
(-4.08)\end{array}$ \\
\hline Mean & 1.33 & 1.19 & $\begin{array}{c}0.14 \\
(0.52)\end{array}$ \\
\hline Median & 1.29 & 1.90 & $\begin{array}{c}-0.61 \\
(-1.63)\end{array}$ \\
\hline \multicolumn{4}{|c|}{ C. Volatility of Growth } \\
\hline Mean & 4.71 & 4.17 & $\begin{array}{c}0.54 \\
(1.54)\end{array}$ \\
\hline Median & 3.65 & 2.89 & $\begin{array}{c}0.76 \\
(2.32) \\
\end{array}$ \\
\hline
\end{tabular}

a: Number of observations with data for inflation is 760, of which 249 are strictly dollarized and 511 belong to an ICU. There are 1,332 observations with data for per capita growth, of which 526 belong to strictly dollarized country and 806 to an ICU.

${ }^{b}$ : Number of observations with data on inflation is 2,732 and there are 3,907 observations with data for per capita GDP growth.

*: Number in parentheses are t-statistics 
TABLE 3

Common Currencies and GDP Growth:

A Treatment Effects Model*

(Maximum Likelihood)

\begin{tabular}{|c|c|c|c|c|c|c|}
\hline & ODEL 1 & AODEL 2 & MODEL 3 & MODEL 4 & MODEL 5 & ODEL 6 \\
\hline $\log \left(G^{\prime} P_{0}\right)$ & $\begin{array}{c}-0.399 \\
(-5.87) \\
2.573\end{array}$ & $\begin{array}{c}-0.449 \\
(-5.24) \\
2.536\end{array}$ & $\begin{array}{c}-0.506 \\
(-5.82) \\
2.465\end{array}$ & $\begin{array}{c}-0.438 \\
(-4.57) \\
2.587\end{array}$ & $\begin{array}{c}-0.464 \\
(-3.85) \\
2.509\end{array}$ & $\begin{array}{c}-0.532 \\
(-3.85) \\
2.429\end{array}$ \\
\hline OPEN & $(986)$ & $(9.55)$ & $\begin{array}{r}(9.26) \\
-3.668\end{array}$ & $(7.04)$ & $(6.82)$ & $\begin{array}{r}(6.61) \\
-4.308\end{array}$ \\
\hline TROPIC & $-\overline{872}$ & $\overline{75}$ & & -- & -- & $\begin{array}{c}(-3.11) \\
1.204\end{array}$ \\
\hline DUMMY & (2.71) & $\begin{array}{r}(2.15) \\
-0.747\end{array}$ & $\begin{array}{r}(2.86) \\
-1.813\end{array}$ & (2.17) & $\begin{array}{r}(1.94) \\
-0.682\end{array}$ & $\begin{array}{r}(2.17) \\
-1.918\end{array}$ \\
\hline EUROPE & -- & $\begin{array}{c}(-2.27) \\
0.136\end{array}$ & $\begin{array}{c}(-4.15) \\
0.234\end{array}$ & -- & $\begin{array}{c}(-1.48) \\
0.145\end{array}$ & $\begin{array}{c}(-3.16) \\
0.266\end{array}$ \\
\hline LAC & -- & $\begin{array}{r}(0.46) \\
-0.493\end{array}$ & $\begin{array}{l}(0.79) \\
-0.849\end{array}$ & -- & $\begin{array}{l}(0.35) \\
-0.608\end{array}$ & $\begin{array}{r}(0.64) \\
-1.010\end{array}$ \\
\hline MENA & -- & $\begin{array}{c}(-1.30) \\
0.126\end{array}$ & $\begin{array}{l}(-2.17) \\
-0.416\end{array}$ & -- & $\begin{array}{c}(-1.13) \\
0.176\end{array}$ & $\begin{array}{l}(-1.84) \\
-0.460\end{array}$ \\
\hline NORTH & -- & $\begin{array}{l}(0.16) \\
0.877\end{array}$ & $\begin{array}{c}(-0.52) \\
0.536\end{array}$ & -- & $\begin{array}{l}(0.16) \\
1.106\end{array}$ & $\begin{array}{c}(-0.41) \\
0.728\end{array}$ \\
\hline SASIA & -- & $\begin{array}{r}(1.73) \\
-1.630\end{array}$ & $\begin{array}{l}(1.04) \\
-1.509\end{array}$ & -- & $\begin{array}{r}(1.54) \\
-1.520\end{array}$ & $\begin{array}{r}(1.00) \\
-1.362\end{array}$ \\
\hline AFRICA & -- & $(-5.40)$ & $(-4.98)$ & -- & $(-3.52)$ & $(-3.15)$ \\
\hline Constant & $\begin{array}{l}3.297 \\
(6.86)\end{array}$ & $\begin{array}{l}4.234 \\
(6.93)\end{array}$ & $\begin{array}{l}3.861 \\
(6.24)\end{array}$ & $\begin{array}{l}3.361 \\
(4.91)\end{array}$ & $\begin{array}{l}4.112 \\
(4.77)\end{array}$ & $\begin{array}{l}3.659 \\
(4.19)\end{array}$ \\
\hline \multicolumn{7}{|c|}{ Treatment Equation } \\
\hline Loq(POP & $\begin{array}{c}-0.462 \\
(-29.38) \\
-0.129\end{array}$ & $\begin{array}{c}-0.463 \\
(-29.47) \\
-0.130\end{array}$ & $\begin{array}{c}-0.463 \\
(-29.46) \\
-0.129\end{array}$ & $\begin{array}{c}-0.490 \\
(-12.93) \\
-0.122\end{array}$ & $\begin{array}{c}-0.493 \\
(-13.12) \\
-0.123\end{array}$ & $\begin{array}{c}-0.492 \\
(-13.06) \\
-0.121\end{array}$ \\
\hline $\log \left(\mathrm{GDP}_{0}\right)$ & $\begin{array}{l}(-6.88) \\
-1.025\end{array}$ & $\begin{array}{l}(-6.91) \\
-1.026\end{array}$ & $\begin{array}{l}(-6.88) \\
-1.025\end{array}$ & $\begin{array}{l}(-2.73) \\
-0.554\end{array}$ & $\begin{array}{l}(-2.73) \\
-0.535\end{array}$ & $\begin{array}{l}(-2.70) \\
-0.539\end{array}$ \\
\hline INDEP & $(-1298)$ & $(-12.97)$ & $(-12.95)$ & $(-3.47)$ & $(-3.34)$ & $(-3.37)$ \\
\hline BORDER & $\begin{array}{r}(-1.43) \\
0.115\end{array}$ & $\begin{array}{r}(-1.45) \\
0.116\end{array}$ & $\begin{array}{c}(-1.45) \\
0.115\end{array}$ & $\begin{array}{l}(-0.43) \\
0.240\end{array}$ & $\begin{array}{l}(-0.65) \\
0.241\end{array}$ & $\begin{array}{c}-0.122 \\
(-0.64) \\
0.237\end{array}$ \\
\hline OPE & $\begin{array}{l}(1.57) \\
-0.992\end{array}$ & $\begin{array}{r}(1.58) \\
-1.006\end{array}$ & $\begin{array}{r}(1.57) \\
-1.005\end{array}$ & $\begin{array}{l}(1.42) \\
-0.848\end{array}$ & $\begin{array}{r}(1.43) \\
-0.898\end{array}$ & $\begin{array}{r}(1.40) \\
-0.889\end{array}$ \\
\hline ISLAND & $\begin{array}{c}(-14.01) \\
0.524\end{array}$ & $\begin{array}{c}(-14.27) \\
0.521\end{array}$ & $\begin{array}{c}(-14.25) \\
0.523\end{array}$ & $\begin{array}{c}(-5.09) \\
0.749\end{array}$ & $\begin{array}{c}(-5.45) \\
0.739\end{array}$ & $\begin{array}{c}(-5.40) \\
0.748\end{array}$ \\
\hline DISTANC & $\begin{array}{l}(7.16) \\
3.531\end{array}$ & $\begin{array}{l}(7.13) \\
3.574\end{array}$ & $\begin{array}{l}(7.16) \\
3.552\end{array}$ & $\begin{array}{l}(4.50) \\
1.390\end{array}$ & $\begin{array}{l}(4.43) \\
1.536\end{array}$ & $\begin{array}{l}(4.48) \\
1.431\end{array}$ \\
\hline Cor & & & & $(0.83)$ & $(0.92)$ & $(0.85)$ \\
\hline Number of obs & 5233 & 5233 & 5233 & 950 & 950 & 950 \\
\hline LR chi2 & 5.58 & 5.70 & 5.44 & 3.54 & 3.54 & 3.54 \\
\hline Prob > chi2 & 0.018 & 0.016 & 0.020 & 0.060 & 0.060 & 0.060 \\
\hline
\end{tabular}

* The upper panel contains the outcome equation. The lower panel contains the estimation of the treatment equation, or equation on the probability of being a "common currency country." The numbers in parentheses are t-statistics. 
TABLE 4

Common Currencies and Inflation: A Treatment Effects Model*

\begin{tabular}{|c|c|c|c|}
\hline & ODEL 1 & MODEL 2 & MODEL 3 \\
\hline OPEN & $\begin{array}{l}-8.591 \\
(-9.14)\end{array}$ & $\begin{array}{l}-9.089 \\
(-9.31)\end{array}$ & $\begin{array}{l}-8.059 \\
(-7.84)\end{array}$ \\
\hline & 1.575 & 3.256 & 6.941 \\
\hline DISTANCE & $(1.82)$ & $\begin{array}{l}(2.62) \\
-6.252\end{array}$ & $\begin{array}{l}(3.77) \\
-9.501\end{array}$ \\
\hline TROPIC & -- & $(-1.89)$ & $(-2.47)$ \\
\hline INFLATION T - 1 & $\begin{array}{c}0.089 \\
(18.57) \\
-0.003\end{array}$ & $\begin{array}{c}0.089 \\
(18.44) \\
-0.003\end{array}$ & $\begin{array}{c}0.085 \\
(17.93) \\
-0.003\end{array}$ \\
\hline INFLATION $_{\text {T - } 2}$ & $\begin{array}{r}(-2.41) \\
-12.233\end{array}$ & $\begin{array}{r}(-2.38) \\
-11.991\end{array}$ & $\begin{array}{l}-2.58) \\
-14.434\end{array}$ \\
\hline DUMMY & $(-7.99)$ & $(-7.80)$ & $\begin{array}{l}(-9.47) \\
10.226\end{array}$ \\
\hline EUROPE & -- & -- & $\begin{array}{l}(3.88) \\
10.259\end{array}$ \\
\hline LAC & -- & -- & $\begin{array}{l}(8.72) \\
3.997\end{array}$ \\
\hline MENA & -- & -- & $\begin{array}{l}(2.08) \\
2.546\end{array}$ \\
\hline NORTHAM & -- & -- & $\begin{array}{l}(0.80) \\
1.974\end{array}$ \\
\hline SASIA & -- & -- & $\begin{array}{l}(1.03) \\
10.631\end{array}$ \\
\hline AFRICA & -- & -- & $(8.76)$ \\
\hline Constant & $\begin{array}{l}4.678 \\
(0.62)\end{array}$ & $\begin{array}{c}-11.381 \\
(1.00)\end{array}$ & $\begin{array}{c}-11.381 \\
(1.00)\end{array}$ \\
\hline \multicolumn{4}{|c|}{ Treatment Equation } \\
\hline Log(POP) & $\begin{array}{c}-0.585 \\
(-23.75) \\
-0.320\end{array}$ & $\begin{array}{c}-0.585 \\
(-23.75) \\
-0.320\end{array}$ & $\begin{array}{c}-0.585 \\
(-23.75) \\
-0.320\end{array}$ \\
\hline $\log \left(G P_{0}\right)$ & $\begin{array}{l}(-9.31) \\
-1.319\end{array}$ & $\begin{array}{l}(-9.31) \\
-1.319\end{array}$ & $\begin{array}{l}(-9.31) \\
-1.319\end{array}$ \\
\hline INDEP & $\begin{array}{l}(-9.06) \\
-0.671\end{array}$ & $\begin{array}{l}(-9.06) \\
-0.671\end{array}$ & $\begin{array}{l}(-9.06) \\
-0.671\end{array}$ \\
\hline BORDER & $\begin{array}{c}(--5.29) \\
0.146\end{array}$ & $\begin{array}{c}(--5.29) \\
0.146\end{array}$ & $\begin{array}{c}(--5.29) \\
0.146\end{array}$ \\
\hline OPEN & $\begin{array}{l}(1.41) \\
-1.511\end{array}$ & $\begin{array}{l}(1.41) \\
-1.511\end{array}$ & $\begin{array}{l}(1.41) \\
-1.511\end{array}$ \\
\hline ISLAND & $\begin{array}{c}(-14.73) \\
0.350\end{array}$ & $\begin{array}{c}(-14.73) \\
0.350\end{array}$ & $\begin{array}{c}(-14.73) \\
0.350\end{array}$ \\
\hline DISTANCE & $\begin{array}{l}(3.03) \\
14.843\end{array}$ & $\begin{array}{l}(3.03) \\
14.843\end{array}$ & $\begin{array}{l}(3.03) \\
14.843\end{array}$ \\
\hline Constant & $(4.73)$ & $(4.73)$ & $(4.73)$ \\
\hline Number of obs & 3122 & 3122 & 3122 \\
\hline LR chi2 & 6.75 & 6.75 & 6.75 \\
\hline Prob > chi2 & 0.027 & 0.027 & 0.027 \\
\hline
\end{tabular}

* The upper panel contains the outcome equation. The lower panel contains the estimation of the treatment equation, or equation on the probability of being a "common currency country." The numbers in parentheses are t-statistics. 
TABLE 5

Common Currencies and Growth Volatility: A Treatment Effects Model

\begin{tabular}{|c|c|c|c|}
\hline & MODEL 1 & MODEL 2 & MODEL 3 \\
\hline $\log \left(G^{\prime} P_{0}\right)$ & $\begin{array}{l}0.026 \\
(2.78) \\
-2.471\end{array}$ & $\begin{array}{l}0.034 \\
(3.24) \\
-2.392\end{array}$ & $\begin{array}{l}0.024 \\
(2.08) \\
-2.148\end{array}$ \\
\hline OPEN & $(-6.78)$ & $\begin{array}{c}(-6.55) \\
1.468\end{array}$ & $\begin{array}{c}(-5.92) \\
3.289\end{array}$ \\
\hline TROPIC & $2 . \overline{--}$ & $\begin{array}{l}(1.65) \\
2.178\end{array}$ & $\begin{array}{l}(2.51) \\
2.457\end{array}$ \\
\hline DUMMY & (5.83) & (3.27) & $\begin{array}{l}(3.80) \\
0.660\end{array}$ \\
\hline EUROPE & -- & -- & $\begin{array}{l}(1.14) \\
1.021\end{array}$ \\
\hline LAC & -- & -- & $\begin{array}{l}(1.01) \\
2.334\end{array}$ \\
\hline MENA & -- & -- & $\begin{array}{l}(4.45) \\
-0.871\end{array}$ \\
\hline NORTHAM & -- & -- & $\begin{array}{l}(-0.81) \\
-1.031\end{array}$ \\
\hline SASIA & -- & -- & $\begin{array}{l}(-1.49) \\
-0.092\end{array}$ \\
\hline AFRICA & $2 . \overline{353}$ & $2 . \overline{225}$ & $\begin{array}{l}(-0.23) \\
2.225\end{array}$ \\
\hline Constant & (3.47) & (3.27) & (3.27) \\
\hline \multicolumn{4}{|c|}{ Treatment Equation } \\
\hline Log(POP) & $\begin{array}{c}-0.464 \\
(-12.18) \\
-0.151\end{array}$ & $\begin{array}{c}-0.468 \\
(-12.26) \\
-0.159\end{array}$ & $\begin{array}{c}-0.465 \\
(-12.10) \\
-0.160\end{array}$ \\
\hline $\log \left(G^{\prime} P_{0}\right)$ & $\begin{array}{l}(-3.44) \\
-1.336\end{array}$ & $\begin{array}{l}(-3.59) \\
-1.341\end{array}$ & $\begin{array}{l}(-3.65) \\
-1.398\end{array}$ \\
\hline INDEP & $\begin{array}{l}(-6.82) \\
-0.090\end{array}$ & $\begin{array}{l}(-6.82) \\
-0.078\end{array}$ & $\begin{array}{l}(-7.11) \\
-0.075\end{array}$ \\
\hline BORDER & $\begin{array}{c}(-0.48) \\
0.184\end{array}$ & $\begin{array}{c}(-0.42) \\
0.186\end{array}$ & $\begin{array}{r}(-0.40) \\
0.196\end{array}$ \\
\hline OPEN & $\begin{array}{l}(1.96) \\
-1.170\end{array}$ & $\begin{array}{l}(1.36) \\
-1.172\end{array}$ & $\begin{array}{l}(1.31) \\
-1.139\end{array}$ \\
\hline ISLAND & $\begin{array}{l}(-7.13) \\
0.586\end{array}$ & $\begin{array}{l}(-7.12) \\
0.541\end{array}$ & $\begin{array}{l}(-6.91) \\
0.571\end{array}$ \\
\hline DISTANCE & $\begin{array}{l}(3.58) \\
3.514\end{array}$ & $\begin{array}{l}(3.23) \\
4.016\end{array}$ & $\begin{array}{l}(3.36) \\
3.752\end{array}$ \\
\hline Constant & $(2.07)$ & (2.31) & (2.12) \\
\hline Number of obs & 950 & 950 & 950 \\
\hline LR chi2 & 34.71 & 28.98 & 32.99 \\
\hline Prob > chi2 & 0.0 & 0.0 & 0.0 \\
\hline
\end{tabular}

* The upper panel contains the outcome equation. The lower panel contains the estimation of the treatment equation, or equation on the probability of being a "common currency country." The numbers in parentheses are t-statistics. 
TABLE 6

Independent Currency Unions, Strict Dollarization, and GDP Growth:

A Treatment Effects Model

\begin{tabular}{|c|c|c|c|c|}
\hline & MODEL 1 & MODEL 2 & MODEL 3 & MODEL 4 \\
\hline $\log \left(G P_{0}\right)$ & $\begin{array}{l}-0.566 \\
(-6.46) \\
3.227\end{array}$ & $\begin{array}{l}-0.545 \\
(-4.40) \\
3.319\end{array}$ & $\begin{array}{l}-0.501 \\
(-5.18) \\
2.658\end{array}$ & $\begin{array}{l}-0.591 \\
(-4.72) \\
3.281\end{array}$ \\
\hline OPEN & $\begin{array}{l}(10.66) \\
-3.041\end{array}$ & $\begin{array}{l}(7.66) \\
-3.299\end{array}$ & $\begin{array}{l}(9.68) \\
-2.601\end{array}$ & $\begin{array}{l}(7.60) \\
-3.300\end{array}$ \\
\hline TROPIC & $\begin{array}{l}(-3.03) \\
2.041\end{array}$ & $\begin{array}{l}(-2.31) \\
2.723\end{array}$ & $(-2.47)$ & $(-2.31)$ \\
\hline DUMMY ICU & $(4.31)$ & $(3.68)$ & $\overline{--}$ & $\overline{--}$ \\
\hline DUMMY DOLLARIZATION & $\begin{array}{c}-- \\
-1.644\end{array}$ & $-\overline{-}$ & $\begin{array}{r}(0.63) \\
-1.606\end{array}$ & $\begin{array}{r}(0.84) \\
-1666\end{array}$ \\
\hline EUROPE & $\begin{array}{l}(-3.70) \\
-0.050\end{array}$ & $\begin{array}{l}(-3.78) \\
-0.150\end{array}$ & $\begin{array}{l}(-3.57) \\
-0.102\end{array}$ & $\begin{array}{l}(-2.61) \\
-0.098\end{array}$ \\
\hline LAC & $\begin{array}{l}(-0.16) \\
-0.861\end{array}$ & $\begin{array}{l}(-0.34) \\
-1.070\end{array}$ & $\begin{array}{l}(-0.32) \\
-0.863\end{array}$ & $\begin{array}{l}(-0.21) \\
-0.998\end{array}$ \\
\hline MENA & $\begin{array}{l}(-2.17) \\
-0.640\end{array}$ & $\begin{array}{l}(-1.90) \\
-0.719\end{array}$ & $\begin{array}{l}(-2.14) \\
-0.477\end{array}$ & $\begin{array}{l}(-1.73) \\
-0.630\end{array}$ \\
\hline NORTHAM & $\begin{array}{c}(-0.81) \\
0.329\end{array}$ & $\begin{array}{c}(-0.64) \\
0.454\end{array}$ & $\begin{array}{c}(-0.81) \\
0.413\end{array}$ & $\begin{array}{c}(-0.55) \\
0.594\end{array}$ \\
\hline SASIA & $\begin{array}{r}(0.64) \\
-2.113\end{array}$ & $\begin{array}{l}(0.62) \\
-2.184\end{array}$ & $\begin{array}{l}(0.77) \\
-1.690\end{array}$ & $\begin{array}{l}(0.87) \\
-1.580\end{array}$ \\
\hline AFRICA & $\begin{array}{c}(-6.46) \\
4.415\end{array}$ & $\begin{array}{c}(-3.68) \\
4.315\end{array}$ & $\begin{array}{c}(-4.92) \\
4.181\end{array}$ & $\begin{array}{c}(-3.19) \\
4.181\end{array}$ \\
\hline Constant & $(6.93)$ & $(4.71)$ & $(6.52)$ & $(6.52)$ \\
\hline \multicolumn{5}{|l|}{ TREATMENT EQUATION } \\
\hline Log(POP) & $\begin{array}{c}-0.345 \\
(-16.62) \\
-0.105\end{array}$ & $\begin{array}{l}-0.386 \\
(-7.83) \\
-0.095\end{array}$ & $\begin{array}{c}-0.524 \\
(-22.71) \\
-0.030\end{array}$ & $\begin{array}{l}-0.542 \\
(-9.44) \\
-0.080\end{array}$ \\
\hline $\log \left(G D P_{0}\right)$ & $\begin{array}{l}(-5.32) \\
-0.808\end{array}$ & $\begin{array}{l}(-1.94) \\
-0.238\end{array}$ & $\begin{array}{l}(-0.80) \\
-1.253\end{array}$ & $\begin{array}{l}(-0.90) \\
-1.333\end{array}$ \\
\hline INDEP & $\begin{array}{l}(-7.73) \\
-1.176\end{array}$ & $\begin{array}{l}(-1.70) \\
-1.032\end{array}$ & $\begin{array}{c}(-12.78) \\
0.169\end{array}$ & $\begin{array}{c}(-5.77) \\
0.388\end{array}$ \\
\hline BORDER & $\begin{array}{l}(--7.64) \\
-3.831\end{array}$ & $\begin{array}{l}(-3.05) \\
-3.654\end{array}$ & $\begin{array}{l}(1.61) \\
1.047\end{array}$ & $\begin{array}{l}(1.54) \\
1.276\end{array}$ \\
\hline OPEN & $\begin{array}{l}(-8.40) \\
-0.744\end{array}$ & $\begin{array}{l}(-3.23) \\
-0.692\end{array}$ & $\begin{array}{l}(10.35) \\
-0.561\end{array}$ & $\begin{array}{l}(5.49) \\
-0.89\end{array}$ \\
\hline ISLAND & $\begin{array}{c}(-8.47) \\
1.240\end{array}$ & $\begin{array}{c}(-3.30) \\
1.407\end{array}$ & $\begin{array}{c}(-5.68) \\
0.347\end{array}$ & $\begin{array}{c}(-2.01) \\
0.581\end{array}$ \\
\hline DISTANCE & $\begin{array}{l}(11.90) \\
-4.826\end{array}$ & $\begin{array}{l}(5.83) \\
-6.345\end{array}$ & $\begin{array}{l}(2.79) \\
4.003\end{array}$ & $\begin{array}{l}(2.09) \\
2.434\end{array}$ \\
\hline Constant & $(-4.70)$ & $(-2.69)$ & $(3.06)$ & $(0.83)$ \\
\hline Number of obs & 4707 & 856 & 4427 & 856 \\
\hline LR chi2 & 4.16 & 2.68 & 3.97 & 4.23 \\
\hline Prob > chi2 & 0.040 & 0.102 & 0.050 & 0.038 \\
\hline
\end{tabular}

*The upper panel contains the outcome equation. The lower panel contains the estimation of the treatment equation, or equation on the probability of being a "common currency country." The numbers in parentheses are t-statistics. 
TABLE 7

Independent Currency Unions, Strict Dollarization, and Inflation:

A Treatment Effects Model

\begin{tabular}{|c|c|c|}
\hline & MODEL 1 & MODEL 2 \\
\hline OPEN & $\begin{array}{c}-10.137 \\
(-8.26) \\
6.983\end{array}$ & $\begin{array}{c}-8.337 \\
(-7.55) \\
6.223\end{array}$ \\
\hline DISTANCE & $\begin{array}{c}(1.94) \\
-11.231\end{array}$ & $\begin{array}{c}(3.07) \\
-11.031\end{array}$ \\
\hline TROPIC & $\begin{array}{c}(-2.76) \\
0.084\end{array}$ & $\begin{array}{c}(-2.59) \\
0.084\end{array}$ \\
\hline INFLATION $_{\mathrm{T}-1}$ & $\begin{array}{l}(17.96) \\
-0.003\end{array}$ & $\begin{array}{c}(16.75) \\
-0.003\end{array}$ \\
\hline INFLATION $_{\mathrm{T}-2}$ & $\begin{array}{c}(-2.42) \\
-20.970\end{array}$ & $(-2.46)$ \\
\hline DUMMY ICU & $(-9.52)$ & $\begin{array}{c}-- \\
-10.026\end{array}$ \\
\hline DUMMY DOLLARIZATION & $\begin{array}{c}-- \\
9.760\end{array}$ & $\begin{array}{c}(-4.79) \\
9.413\end{array}$ \\
\hline EUROPE & $\begin{array}{l}(1.31) \\
10.724\end{array}$ & $\begin{array}{l}(3.33) \\
10.776\end{array}$ \\
\hline LAC & $\begin{array}{l}(7.42) \\
3.690\end{array}$ & $\begin{array}{l}(8.45) \\
3.800\end{array}$ \\
\hline MENA & $\begin{array}{l}(2.00) \\
3.467\end{array}$ & $\begin{array}{l}(1.86) \\
2.802\end{array}$ \\
\hline NORTHAM & $\begin{array}{l}(1.05) \\
2.107\end{array}$ & $\begin{array}{l}(0.83) \\
1.169\end{array}$ \\
\hline SASIA & $\begin{array}{l}(1.04) \\
12.232\end{array}$ & $\begin{array}{l}(0.56) \\
12.167\end{array}$ \\
\hline AFRICA & $\begin{array}{c}(8.76) \\
-51.319\end{array}$ & $\begin{array}{c}(8.62) \\
-46.204\end{array}$ \\
\hline Constant & $(-2.92)$ & $(-2.92)$ \\
\hline \multicolumn{3}{|l|}{ TREATMENT EQUATION } \\
\hline $\log (P O P)$ & $\begin{array}{c}-0.492 \\
(-16.30) \\
-0.250\end{array}$ & $\begin{array}{c}-0.881 \\
(-14.78) \\
-0.433\end{array}$ \\
\hline $\log \left(G P_{0}\right)$ & $\begin{array}{l}(-6.85) \\
-0.260\end{array}$ & $\begin{array}{l}(-5.82) \\
-1.967\end{array}$ \\
\hline INDEP & $\begin{array}{c}(-1.44) \\
0.146\end{array}$ & $\begin{array}{c}(-9.80) \\
2.418\end{array}$ \\
\hline OPEN & $\begin{array}{l}(1.41) \\
-1.581\end{array}$ & $\begin{array}{l}(11.05) \\
-1.352\end{array}$ \\
\hline ISLAND & $\begin{array}{c}(-12.76) \\
0.180\end{array}$ & $\begin{array}{l}(-7.63) \\
-0.031\end{array}$ \\
\hline DISTANCE & $\begin{array}{l}(1.29) \\
7.443\end{array}$ & $\begin{array}{l}(-0.41) \\
15.533\end{array}$ \\
\hline Constant & $(4.85)$ & $(4.85)$ \\
\hline Number of obs & 2925 & 2676 \\
\hline LR chi2 & 6.15 & 4.29 \\
\hline Prob > chi2 & 0.02 & 0.04 \\
\hline
\end{tabular}

* The upper panel contains the outcome equation. The lower panel contains the estimation of the treatment equation, or equation on the probability of being a "common currency country." The numbers in parentheses are t-statistics. 
TABLE 8

Independent Currency Unions, Strict Dollarization, and Volatility:

A Treatment Effects Model

\begin{tabular}{|c|c|c|}
\hline & MODEL 1 & MODEL 2 \\
\hline $\log \left(\mathrm{GDP}_{0}\right)$ & $\begin{array}{l}0.321 \\
(2.70) \\
-1.771\end{array}$ & $\begin{array}{l}0.287 \\
(2.22) \\
-2.549\end{array}$ \\
\hline OPEN & $\begin{array}{r}(-4.36) \\
1933\end{array}$ & $\begin{array}{c}(-7.00) \\
4389\end{array}$ \\
\hline TROPIC & $\begin{array}{l}(1.54) \\
2.271\end{array}$ & $(3.15)$ \\
\hline DUMMY ICU & (3.62) & 2. \\
\hline DUMMY DOLLARIZATION & $\begin{array}{c}-- \\
0.654\end{array}$ & $\begin{array}{l}(4.07) \\
0.644\end{array}$ \\
\hline EUROPE & $\begin{array}{r}(1.11) \\
-0.053\end{array}$ & $\begin{array}{r}(1.07) \\
-0.087\end{array}$ \\
\hline LAC & $\begin{array}{c}(-1.21) \\
2.567\end{array}$ & $\begin{array}{c}(-0.21) \\
2.330\end{array}$ \\
\hline MENA & $\begin{array}{r}(4.87) \\
-1.115\end{array}$ & $\begin{array}{c}(4.34) \\
-0.880\end{array}$ \\
\hline NORTHAM & $\begin{array}{l}(-1.05) \\
-0.569\end{array}$ & $\begin{array}{l}(-0.82) \\
-1.403\end{array}$ \\
\hline SASIA & $\begin{array}{c}(-0.83) \\
0.607\end{array}$ & $\begin{array}{c}(-1.95) \\
0.305\end{array}$ \\
\hline AFRICA & $\begin{array}{l}(1.39) \\
2.035\end{array}$ & $\begin{array}{l}(0.66) \\
3.756\end{array}$ \\
\hline Constant & $(2.35)$ & $(4.37)$ \\
\hline \multicolumn{3}{|l|}{ TREATMENT EQUATION } \\
\hline $\log (P O P)$ & $\begin{array}{l}-0.370 \\
(-7.59) \\
-0.133\end{array}$ & $\begin{array}{l}-0.548 \\
(-9.50) \\
-0.139\end{array}$ \\
\hline $\log \left(G P_{0}\right)$ & $\begin{array}{l}(-2.91) \\
-1.115\end{array}$ & $\begin{array}{l}(-1.55) \\
-1.608\end{array}$ \\
\hline INDEP & $\begin{array}{l}(-4.26) \\
-0.824\end{array}$ & $\begin{array}{c}(-6.44) \\
0.294\end{array}$ \\
\hline BORDER & $\begin{array}{l}(-2.29) \\
-3.795\end{array}$ & $\begin{array}{l}(1.17) \\
1.167\end{array}$ \\
\hline OPEN & $\begin{array}{l}(-3.36) \\
-0.969\end{array}$ & $\begin{array}{c}(4.81) \\
-0.689\end{array}$ \\
\hline ISLAND & $\begin{array}{c}(-4.73) \\
1.130\end{array}$ & $\begin{array}{c}(-2.86) \\
0.338\end{array}$ \\
\hline DISTANCE & $\begin{array}{r}(4.79) \\
-2.928\end{array}$ & $\begin{array}{l}(1.11) \\
5.569\end{array}$ \\
\hline Constant & $(-1.25)$ & $(1.75)$ \\
\hline Number of obs & 855 & 806 \\
\hline LR chi2 & 14.19 & 14.78 \\
\hline Prob > chi2 & 0.0 & 0.0 \\
\hline
\end{tabular}

* The upper panel contains the outcome equation. The lower panel contains the estimation of the treatment equation, or equation on the probability of being a "common currency country." The numbers in parentheses are t-statistics. 
TABLE 9: Common Currencies, ICUs and Dollarization:

Matching Estimators, Mean Differences*

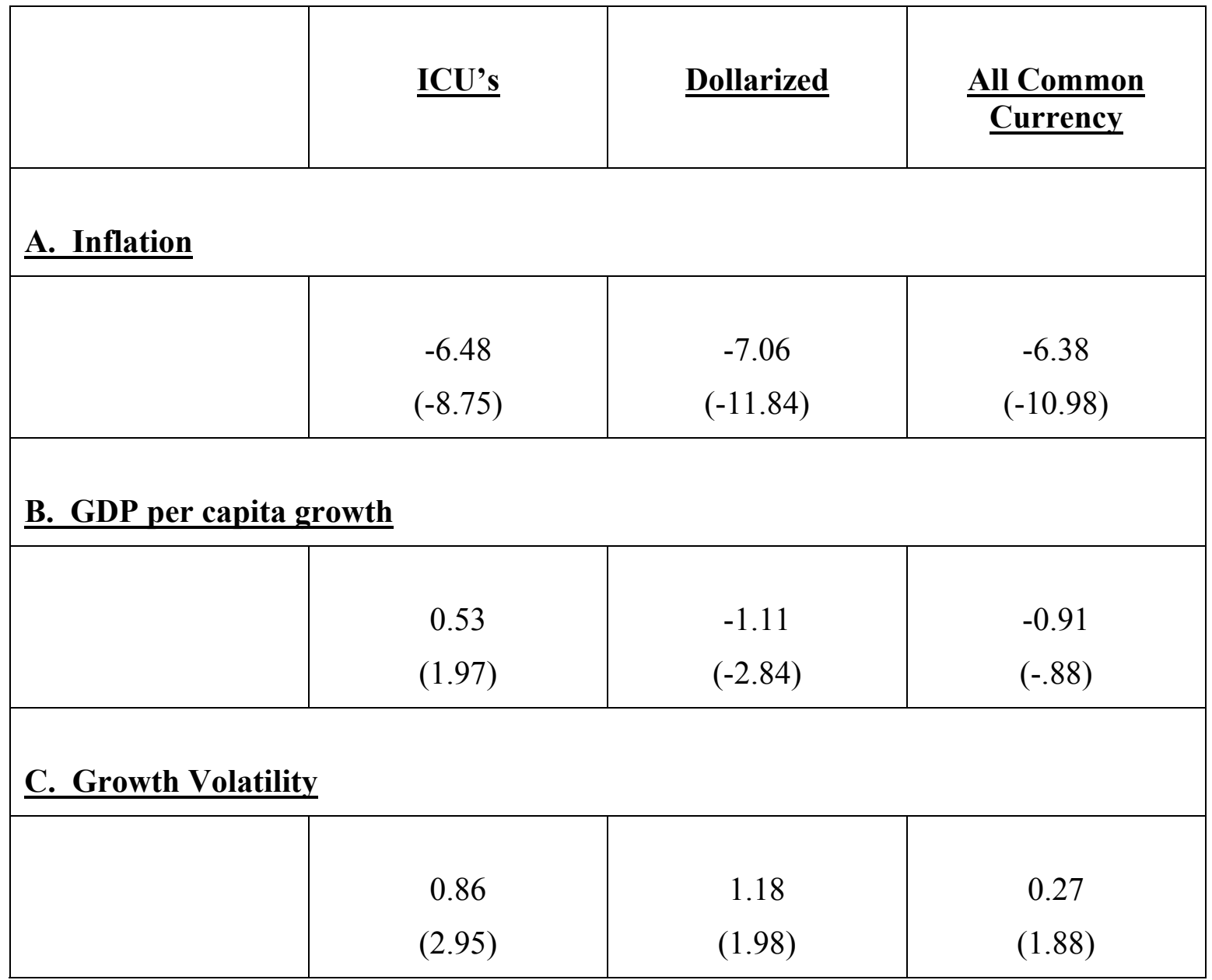

*: The results reported in this table correspond to the five-nearest neighbors without replacement. The numbers in parentheses are t-statistics. 